\title{
Orphan nuclear receptors in angiogenesis and follicular development
}

\author{
Adrian Guzmán ${ }^{1,2}$, Camilla H K Hughes ${ }^{1}$ and Bruce D Murphy ${ }^{1}$ \\ ${ }^{1}$ Centre de Recherche en Reproduction et Fertilité, Université de Montréal, St-Hyacinthe, Quebec, Canada and \\ 2 Departamento de Producción Agrícola y Animal, Universidad Autónoma Metropolitana-Xochimilco, México \\ Distrito Federal, México
}

Correspondence should be addressed to B D Murphy; Email: bruce.d.murphy@umontreal.ca

\begin{abstract}
Orphan nuclear receptors (ONRs) are a subset of the nuclear receptor family that lacks known endogenous ligands. Among 48 nuclear receptors identified in humans, 25 are classified as ONRs. They function as transcription factors and control the expression of a wide range of genes to regulate metabolism, fertility, immunity, angiogenesis, and many other functions. Angiogenic factors are essential during ovarian follicle development, including follicle growth and ovulation. The correct development of blood vessels contributes to preantral and antral follicular development, selection of the dominant follicle or follicles, follicular atresia, and ovulation. Although progress has been made in understanding the molecular mechanisms that regulate follicular angiogenesis, the role of ONRs as regulators is not clear. Based on their functions in other tissues, the ONRs NR1D1 (REV-ERBß), NR2C2 (TR4), NR2F2 (COUP-TF-II) and NR3B1, 2, and 3 (ERR $\alpha$, ERR $\beta$ and ERR $\gamma$ ) may modulate angiogenesis during antral follicle development. We hypothesize that this is achieved by effects on the expression and function of VEGFA, ANGPT1, THBS1, and soluble VEGFR1. Further, angiogenesis during ovulation is expected to be influenced by ONRs. NR5A2 (LRH-1), which is required for ovulation, regulates angiogenic genes in the ovary, including VEGFA and the upstream regulator of angiogenesis, PGE2. These angiogenic molecules may also be regulated by NR5A1 (SF-1). Evidence from outside the reproductive tract suggests that NR2F2 and NR4A1(NUR77) promote VEGFC and PGF, respectively, and NR4As (NUR77, NOR1) seem to be necessary for the angiogenic effects of VEGFA and PGE2. Together, the data suggest that ONRs are important regulators of follicular angiogenesis.

Reproduction (2021) 162 R35-R54
\end{abstract}

\section{Introduction}

The nuclear receptors (NRs) are a superfamily of transcription factors and cofactors that regulate cellular function (Bertolin et al. 2010, Riggins et al. 2010). In humans, 48 NRs have been identified (Benoit et al. 2006, Sonoda et al. 2008, Meinsohn et al. 2019), among which 25 are currently classified as orphan nuclear receptors (ONRs). The ONR genes and their common names are summarized in Table 1. As with other NRs, the ONRs act as transcription factors and cofactors to promote or suppress the transcription of genes. Thus, they control many functions, such as development, metabolism, immunity, steroidogenesis, and angiogenesis (Suntharalingham et al. 2015, Garattini et al. 2016, Bertacchi et al. 2019, Medzikovic et al. 2019).

Angiogenesis is indispensable for successful antral follicle development and is believed to play a role in ovulation (Reynolds \& Redmer 1998, Duffy et al. 2019). During antral follicle development, healthy tertiary follicles and those that are, or will become, dominant have a better developed vasculature than do small antral and atretic follicles (Zeleznik et al. 1981, Wulff et al. 2001). During ovulation, endothelial cells migrate from the theca layer to the inner granulosa layer of the rupturing follicle (Kizuka et al. 2012, Trau et al. 2015, 2016, Kim et al. 2017). Inhibition of angiogenic factors during this period partially or fully blocks ovulation (Kim et al. 2014, Bender et al. 2018). The principal factors that regulate angiogenesis during follicle development and ovulation are vascular endothelial growth factor-A (VEGFA, also referred to as VEGF), placental growth factor (PGF), VEGFC, VEGFD, prostaglandin-E2 (PGE2), angiopoietin-1 and-2 (ANGPT1, ANGPT2) and thrombospondin-1 (THBS1) (Robinson et al. 2009, Rizov et al. 2017, Devesa \& Caicedo 2019, Duffy et al. 2019).

Evidence from studies in nonreproductive tissues indicates that ONRs may regulate one or more of the factors involved in the control of angiogenesis. This has led to the hypothesis that ONRs similarly regulate angiogenesis during follicle growth and ovulation. For instance, NR1D1 (REV-ERB $\alpha), N R 2 C 2$ (TR4), NR2F2 (COUP-TF-II), NR3B1 (ERR $\alpha)$ and NR5A2 (LRH-1) all regulate VEGFA, PGE2 and THBS1 synthesis ( $\mathrm{Li}$ et al. 2014, Zou et al. 2014, Wu et al. 2017, Bianco et al. 2019, Burgermeister et al. 2019, Hu et al. 2020). In the 
Table 1 Names of 25 orphan nuclear receptor and summary of the effect of these on ovarian function and in the control of expression or activity of ovarian angiogenic factors.

\begin{tabular}{|c|c|c|c|c|}
\hline Gene & $\begin{array}{l}\text { Common } \\
\text { name }\end{array}$ & Full name & Function on ovary & $\begin{array}{l}\text { Effect on the expression of genes that } \\
\text { regulate follicular angiogenesis }\end{array}$ \\
\hline NROB1 & DAX-1 & Dosage-sensitive sex reversal & $\begin{array}{l}\text { Not essential but regulates function of } \\
\text { NR5A1 and A2 (Murayama et al. } \\
\text { 2008) }\end{array}$ & Inhibits VEGF (Kang et al. 2015) \\
\hline NROB2 & SHP & Small heterodimer partner & $\begin{array}{l}\text { Not essential (Takae et al. 2019) but may } \\
\text { regulate function of NR5A1 and A2 } \\
\text { (Murayama et al. 2008) }\end{array}$ & Reduces THBS1 (Smalling et al. 2013) \\
\hline NR1D1 & REV-ERB $\alpha$ & Reverse strand of ERB-alpha & $\begin{array}{l}\text { Regulates fertility (deletion causes } \\
\text { subfertility) and steroid synthesis } \\
\text { (Preitner et al. 2002, Chen et al. 2012) }\end{array}$ & $\begin{array}{l}\text { Promotes VEGF (Burgermeister et al. 2019); } \\
\text { Reduces PGE2 synthesis (Isayama et al. 2015); } \\
\text { Reduces THBS1 (Li et al. 2014) }\end{array}$ \\
\hline NR1D2 & REV-ERB $\beta$ & Reverse strand of ERB-beta & & \\
\hline NR1F1 & $\mathrm{ROR} \alpha$ & $\begin{array}{l}\text { Retinoid-related orphan nuclear } \\
\text { receptor-alpha }\end{array}$ & $\begin{array}{l}\text { Mediator of antioxidant effect of } \\
\text { melatonin in cumulus cells } \\
\text { (Fang et al. 2019) }\end{array}$ & $\begin{array}{l}\text { Affects VEGF, direction of change depends on } \\
\text { cell type (Suyama et al. 2016, Sayed et al. } \\
\text { 2019); Promotes PGF (Talia et al. 2016); } \\
\text { Regulated by PGE2 (Shin et al. 2014); } \\
\text { Reduces PGE2 synthesis (Isayama et al. 2015) }\end{array}$ \\
\hline NR1F2 & $\operatorname{ROR} \beta$ & $\begin{array}{l}\text { Retinoid-related orphan nuclear } \\
\text { receptor-beta }\end{array}$ & $\begin{array}{l}\text { Low to absent in ovary (Bookout et al. } \\
\text { 2006) }\end{array}$ & \\
\hline NR1F3 & $\operatorname{ROR} \gamma$ & $\begin{array}{l}\text { Retinoid-related orphan nuclear } \\
\text { receptor-gamma }\end{array}$ & $\begin{array}{l}\text { Moderately abundant in the ovary } \\
\text { (Bookout et al. 2006) }\end{array}$ & $\begin{array}{l}\text { Promotes VEGF (Talia et al. 2016), PGF (Talia } \\
\text { et al. 2016) }\end{array}$ \\
\hline NR2A1 & $\mathrm{HNF} 4 \alpha$ & Hepatocyte nuclear factor 4 -alpha & Not or very lowly expressed & \\
\hline NR2A2 & $\mathrm{HNF} 4 \gamma$ & Hepatocyte nuclear factor 4-gamma & Not or very lowly expressed & \\
\hline NR2C1 & TR2 & Testicular nuclear receptors 2 & Not or very lowly expressed & \\
\hline $\mathrm{NR} 2 \mathrm{C} 2$ & TR4 & Testicular nuclear receptors 4 & $\begin{array}{l}\text { Female mice lacking NR2C2 } \\
\text { (NR2C2-/-) displayed subfertility } \\
\text { (Chen et al. 2008) }\end{array}$ & Promotes VEGF (Hu et al. 2020) \\
\hline NR2E1 & TLX & Nuclear receptor tailless & Not or very lowly expressed & \\
\hline NR2E3 & PNR & $\begin{array}{l}\text { Photoreceptor-specific nuclear } \\
\text { receptor }\end{array}$ & Not or very lowly expressed & \\
\hline NR2F1 & COUP-TFI & $\begin{array}{l}\text { Chick ovalbumin upstream promoter- } \\
\text { transcription factor- } 1\end{array}$ & $\begin{array}{l}\text { Represses gonadotropin receptor } \\
\text { expression (Zhang \& Dufau 2003) }\end{array}$ & \\
\hline NR2F2 & COUP-TF-II & $\begin{array}{l}\text { Chick ovalbumin upstream promoter- } \\
\text { transcription factor- } 2\end{array}$ & $\begin{array}{l}\text { Represses FSH expression but seems to } \\
\text { promote steroidogenesis (Xing et al. } \\
2002 \text { ) }\end{array}$ & $\begin{array}{l}\text { May promote or inhibit VEGF (Qin et al. 2010a, } \\
\text { Zhu et al. 2016); Inhibits VEGFR1 and } \\
\text { sVEGFR1 (Qin et al. 2010a); Increases VEGF-C } \\
\text { (Polvani et al. 2014) }\end{array}$ \\
\hline NR2F6 & EAR2 & V-erb-related gene & $\begin{array}{l}\text { Represses gonadotropin receptor } \\
\text { expression (Zhang \& Dufau 2003) }\end{array}$ & \\
\hline NR3B1 & $\mathrm{ERR} \alpha$ & Estrogen-related receptor alpha & $\begin{array}{l}\text { Regulates steroidogenesis } \\
\text { (Ning et al. 2014), PGC number } \\
\text { (Mitsunaga et al. 2004) }\end{array}$ & $\begin{array}{l}\text { Promotes VEGF (Zou et al. 2014); Reduces } \\
\text { VEGFR2 expression (Likhite et al. 2019), } \\
\text { THBS1 (Wu et al. 2017); Reduced by VEGF } \\
\text { (Likhite et al. 2019); Regulated by PGE2 (Miao } \\
\text { et al. 2010) }\end{array}$ \\
\hline NR3B2 & $\mathrm{ERR} \beta$ & Estrogen-related receptor beta & $\begin{array}{l}\text { Regulates steroidogenesis } \\
\text { (Ning et al. 2014), PGC number } \\
\text { (Mitsunaga et al. 2004) }\end{array}$ & Promotes VEGF (Zou et al. 2014). \\
\hline NR3B3 & $\mathrm{ERR} \gamma$ & Estrogen-related receptor gamma & $\begin{array}{l}\text { Regulates steroidogenesis } \\
\text { (Ning et al. 2014), PGC number } \\
\text { (Mitsunaga et al. 2004) }\end{array}$ & $\begin{array}{l}\text { Promotes VEGF (Zou et al. 2014), ANGPT1 and } \\
\text { ANGPT2 expression (Badin et al. 2016) }\end{array}$ \\
\hline NR4A1 & $\begin{array}{l}\text { Nur77 } \\
\text { TR3 } \\
\text { NGFIB }\end{array}$ & Nerve growth factor- $1 \beta$ & $\begin{array}{l}\text { Regulates steroid synthesis during } \\
\text { ovulation (Hughes \& Murphy 2021) }\end{array}$ & $\begin{array}{l}\text { Regulated by VEGF (Zhou et al. 2016), PGE2 } \\
\text { (Land et al. 2015), ANGPT1 (Ismail et al. } \\
\text { 2012); Promotes PGF (Li et al. 2019) }\end{array}$ \\
\hline NR4A2 & $\begin{array}{l}\text { Nurr1 } \\
\text { RNR-1 } \\
\text { TONOR }\end{array}$ & Nuclear receptor related-1 & $\begin{array}{l}\text { Regulates steroid synthesis during } \\
\text { ovulation (Hughes \& Murphy 2021) }\end{array}$ & $\begin{array}{l}\text { Regulated by VEGF (Zhou et al. 2016); Reduces } \\
\text { THBS2 (McMorrow et al. 2013) }\end{array}$ \\
\hline NR4A3 & Nor1 & Neuron-derived orphan receptor-1 & $\begin{array}{l}\text { Regulates steroid synthesis during } \\
\text { ovulation (Hughes \& Murphy 2021) }\end{array}$ & Regulated by VEGF (Zhou et al. 2016) \\
\hline NR5A1 & SF-1 & Steroidogenic factor- 1 & $\begin{array}{l}\text { Important for ovarian steroidogenesis. } \\
\text { Deletion from the primordial follicle } \\
\text { forward causes infertility (Meinsohn } \\
\text { et al. 2019) }\end{array}$ & $\begin{array}{l}\text { Correlated with VEGF expression (Przygrodzka } \\
\text { et al. 2016); Promotes PGE2 synthesis (Wang } \\
\text { et al. 2019), ANGPT2 expression (Ferraz-de- } \\
\text { Souza et al. 2011) }\end{array}$ \\
\hline NR5A2 & LRH-1 & Liver receptor homolog-1 & $\begin{array}{l}\text { Necessary for ovulation (Duggavathi } \\
\text { et al. 2008, Bertolin et al. 2017) }\end{array}$ & $\begin{array}{l}\text { Promotes VEGF (Bertolin et al. 2014, Bianco } \\
\text { et al. 2019); Promotes expression of PTGS2 } \\
\text { (Duggavathi et al. 2008) }\end{array}$ \\
\hline NR6A1 & GCNF & Germ cell nuclear factor & $\begin{array}{l}\text { In the ovary NR6A1 expression is } \\
\text { restricted to the oocyte } \\
\text { (Zhao et al. 2007) }\end{array}$ & \\
\hline
\end{tabular}


reciprocal sense, ONRs may be regulated by angiogenic factors themselves, as, for example, the expression and activity of the NR4A family (NUR77/TR3/NGFIB, NURR1/RNR-1/TONOR, and NOR1) are regulated by VEGFA, PGE2 and ANGPT1 (Ismail et al. 2012, Land et al. 2015, Zhou et al. 2016, Li et al. 2019). Despite the importance of ONRs in the regulation of angiogenesis and in the control of synthesis and function of ovarian angiogenic factors, the specific roles of these NRs in the ovarian angiogenic context have been not evaluated. However, it is well known that ONRs regulate many aspects of reproduction, including sex steroid synthesis, response to gonadotropins, and ovulation (Xing et al. 2002, Chen et al. 2008, Meinsohn et al. 2019, Hughes \& Murphy 2021). Therefore, the objective of the present manuscript is to review the available literature on both follicular angiogenesis and the role of ONRs in the regulation of angiogenesis, to better understand the potential function of these receptors in the ovary.

\section{Orphan nuclear receptor structure and actions}

The general structure of NRs (Fig. 1A) consists of a highly variable $\mathrm{N}$-terminal domain, a DNA binding domain (DBD), a hinge region, a conserved ligandbinding domain (LBD), and a variable C-terminal domain (Benoit et al. 2006, Sonoda et al. 2008, Porter et al. 2019, Meinsohn et al. 2019). The DBD has two highly conserved zinc-finger motifs unique to NRs. In the N-terminal domain, some NRs may have a ligand-independent $\mathrm{N}$-terminal activation function-1 (AF-1). Additionally, in the C-terminal domain, a liganddependent C-terminal activation function-2 can be present (AF-2) (Zhang et al. 2011a).

NRs were first identified as transcription factors that are, in general, specifically activated by small hydrophobic molecules, such as steroids, thyroid hormone, retinoic acid, vitamin D, and bile acids (Cave et al. 2016, Meinsohn et al. 2019). Generally, NRs act as ligand-inducible transcription factors by directly interacting with DNA response elements of target genes. NRs induce transcription as monomers, homodimers, or heterodimers. The effects of NRs on transcription are mediated through the recruitment of coactivators or corepressors. In response to ligand binding, NRs undergo a conformational change that allows the recruitment of multiple coactivators to induce chromatin remodeling and histone acetylation. In some cases, the NR may interact directly with the basic transcriptional machinery of the cell (Aranda \& Pascual 2001).

In 1999, the Nuclear Receptor Nomenclature Committee published a unified system of nomenclature for the nuclear receptor superfamily. This system is a phylogeny-based nomenclature in the form of NRxyz. NR stands for NR, $x$ identifies the subfamily, numbered 0 to 6 , to which the receptor belongs, $y$ indicates the group within the subfamily designed by a capital letter, and $z$ numbers the individual genes within subfamily, designed by Arabic numerals (Robinson-Rechavi et al. 2003, Novac \& Heinzel 2004). The phylogenetic relationship within each subfamily is indicated by the capital letter $(y)$, with more similar receptors indicated by proximal letters (Novac \& Heinzel 2004).

Members of the NR superfamily have been further categorized based on the number of characteristics, such as dimerization, DNA binding motif, and ligand selectivity (Mangelsdorf et al. 1995, Sonoda et al. 2008). Grouping according to the latter criterion results in three classes of NRs: conventional steroid and thyroid hormone receptors, adopted orphan receptors, for which a ligand has been discovered, and ONRs, for which a ligand either has not been identified or appears to be unnecessary for function (Benoit et al. 2006, Sonoda et al. 2008, Cave et al. 2016, Meinsohn et al. 2019, Tiwari \& Gupta 2021). Although ONRs share the canonical structure of all NRs, each of the 25 ONRs has some particular structural characteristics that define its functions as an activator or repressor of transcription. These structural differences, organized by the phylogenetic family, are summarized Fig. 1B.

\section{Functions and structural variations of ONRs}

NROB1, also known as DAX-1, is a regulator of adrenal development and function and is also necessary for prenatal testicular development and spermatogenesis (reviewed by Lalli \& Alonso 2010, Ravel et al. 2014, Suntharalingham et al. 2015). The closely related NROB2 or SHP controls various aspects of cell metabolism, including cholesterol metabolism, energy homeostasis, and bile acid metabolism, among other functions (Zhang et al. 2001, Chanda et al. 2008, Garattini et al. 2016 for details). Both of these receptors lack several structural components, including the DBD (Fig. 1), and thus act as coactivators or corepressors, rather than directly regulating transcription (Chanda et al. 2008, Zhang et al. 2011a, Ehrlund \& Treuter 2012, Orekhova \& Rubtsov 2015 for details).

ONRs of the NR1 family (NR1D1 or REV-ERB $\alpha$, NR1D2 or REV-ERB $\beta, N R 1 F 1$ or ROR $\alpha, N R 1 F 2$ or $\mathrm{ROR} \beta$ and NR1F3 or ROR $\gamma$ ) are core components of the circadian clock system in mammals (Kojetin \& Burris 2014, Welch \& Flaveny 2017, Wang et al. 2020 for detail). Both NR1D1 and NR1D2 lack the F domain, which is necessary for the activation of ligand-dependent transcriptional activity. This results in the NR1D receptors functioning as repressors of transcription that bind to corepressors, such as NR corepressor 1 (Burris 2008, Solt et al. 2011, Kojetin \& Burris 2014, Lazar 2016 for detail). Members of the retinoid-related orphan receptor family (the members of NR1 group F) have a similar structure to the retinoic acid receptor family, as their common name suggests. In contrast to the function of the NR1D family, the NR1F receptors activate gene expression in 


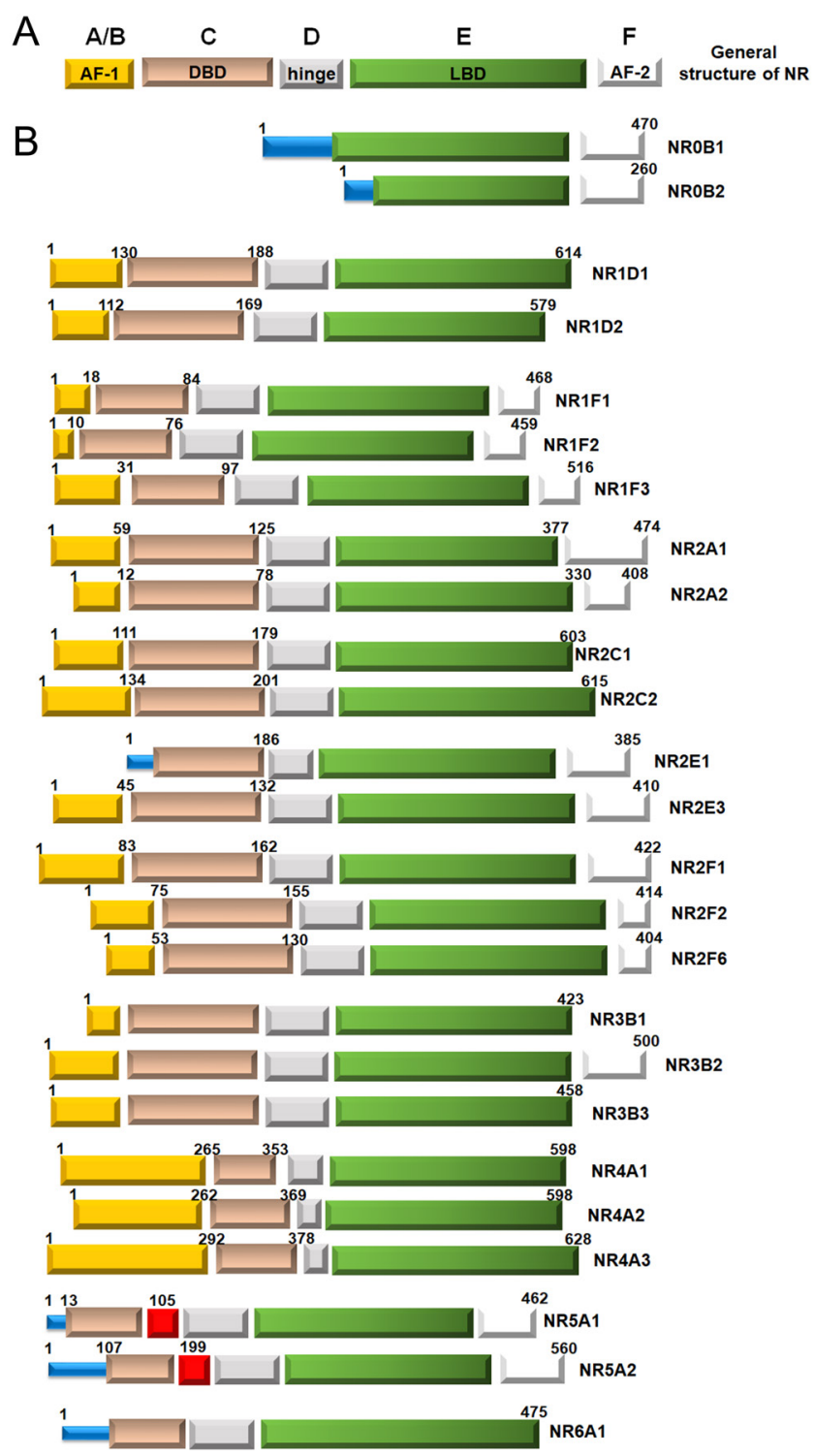

Figure 1 Schematic representation of the general structure of nuclear receptors (A) and particular structural characteristics of the 25 human orphan nuclear receptors (ONR; B). Yellow represents the A/B or AF-1 domain, beige represents the $\mathrm{C}$ or DNA binding domain, gray represents the $\mathrm{D}$ or hinge domain, green represents the $\mathrm{E}$ or ligand binding domain, and white represents the F or AF-2 domain. The blue section in a few ONRs represents the N-terminal region of the ONR where the domain or domains are not present or have been not yet identified. The red section in NR5A1 and 2 represents the FTZ-F1 or A box domain present only in the NR5A receptors. Differences in sizes of domains in each group of ONRs represent differences in the size of protein (Compiled from Maruyama et al. 1998, Taraviras et al. 2000, Chung \& Cooney 2001, Lee et al. 2002, Stein \& McDonnell 2006, Zhang et al. 2011a, Ehrlund \& Treuter 2012, Wang \& Cooney 2013, Hermann-Kleiter \& Baier 2014, Kojetin \& Burris 2014, Lu 2016, Wang \& Xiong 2016, Wu \& Chen 2018, Meinsohn et al. 2019, Al-khuzaei et al. 2020). the absence of ligand binding, by recruiting a variety of cofactors (Kojetin \& Burris 2014).

The nine ONRs that belong to the NR subfamily 2 are implicated in the regulation of several physiological processes, including hepatic function, metabolism, development, testicular function, neuronal and cardiovascular development, and retinal function (Tan et al. 2013, Lu 2016, Lin et al. 2017, Sobhan \& Funa 2017, Bertacchi et al. 2019). NR2A1 (HNF4 $\alpha$ ) has a unique $\mathrm{N}$-terminal dimerization domain, which is necessary for homo- and heterodimerization (Ryffel 2001, Lu 2016). NR2A1 and NR2A2 (HNF4 $\gamma$ ) are similar in structure (Taraviras et al. 2000, Sasaki et al. 2018). NR2C1 (TR2) was one of the first NRs identified in humans (Chang \& Kokontis 1988, Chang et al. 1989). Later, NR2C2 was cloned from human and rat hypothalamus, prostate, and testis (Chang et al. 1994). The protein sequence of NR2C2 has $83 \%$ homology with NR2C1 in the DBD and $57 \%$ in the LBD (Liu et al. 2014). NR2E1 (TLX) constitutively represses gene transcription (Benod et al. 2014, Sobhan \& Funa 2017) and has some unique structural characteristics. In this receptor, the AF-2 domain is present, but the AF-1 domain is not (Benod et al. 2016, Wang \& Xiong 2016, Sobhan \& Funa 2017 for details). NR2E3 (PNR) has the canonical structure of NRs and contains the AF-1 domain, allowing it to act as a repressor or activator of transcription (Schorderet \& Escher 2009, Tan et al. 2013). Both NR2F1 (COUP-TFI) and NR2F2 possess the classical NR domains and may activate or repress the transcription of genes (Tang et al. 2015, Yang et al. 2017, Bertacchi et al. 2019 for detail). The closely related NR2F6 (EAR2) is structurally similar but primarily acts to repress transcription (Raccurt et al. 2005, Hermann-Kleiter \& Baier 2014).

NR3B1 (ERR $\alpha), N R 3 B 2(E R R \beta)$ and NR3B3 (ERR $\gamma)$ are the estrogen-related receptors. They are implicated in regulation of energy metabolism, stem cell biology, and development (Huss et al. 2015, Divekar et al. 2016). As their common name indicates, these ONRs are structurally similar to $E R \alpha$ and $E R \beta$, but with relatively low homology, and are not activated by estrogens (Horard \& Vanacker 2003). In fact, these receptors are constitutively activated, due to a structure that favors exposure of the AF-2 domain (Misawa \& Inoue 2015).

The functions of NR4A1 (NUR77/TR3/NGFIB), NR4A2 (NURR1/RNR-1/TONOR) and NR4A3 (NOR1) include regulation of cellular proliferation and apoptosis, angiogenesis, inflammation, metabolism, heart function, and cancer (Kurakula et al. 2014, Herring et al. 2019, Medzikovic et al. 2019). The protein structure of the NR4A members includes each of the classical NR domains, but the LBD of NR4A1 and NR4A2 has no ligand-binding pocket and therefore lacks the ability to interact with ligands (Wang et al. 2003, Flaig et al. 2005, Pawlak et al. 2015).

NR5A1 (SF-1) and NR5A2 (LRH-1) regulate cholesterol homeostasis, steroidogenesis, cell proliferation, and 
stem cell pluripotency. During embryonic and fetal development, NR5A2 controls development beyond gastrulation, whereas NR5A1 is necessary for the genesis of the adrenal gland, sexual differentiation, and Leydig cell function (Bertolin et al. 2010, Meinsohn et al. 2019). The two NR5As share several important structural characteristics. The $\mathrm{N}$-terminal domain of both these receptors lacks AF-1. Thus, these receptors can be phosphorylated in this region to bind to cofactors, which modify their transcriptional activity (Młynarczuk \& Rękawiecki 2010). Moreover, members of the NR5A subfamily contain an additional 30-amino acid C-terminal extension, designated FTZ-F1 or A box. This permits these ONRs to function as monomers (Meinsohn et al. 2019).

As noted previously, ONRs control a wide variety of functions, such as development, metabolism, immunity, steroidogenesis, and angiogenesis. Nonetheless, information on the role of these receptors in the regulation of ovarian angiogenesis is currently somewhat limited. Our goal in this review is to delineate the potential functions of ONRs in this process based on evidence for their roles in angiogenesis in the ovary and in nonreproductive tissues.

\section{Angiogenesis during follicle growth and ovulation Preovulatory follicles}

Follicular development is initiated when quiescent primordial follicles are activated to join the growing pool of follicles. The supply of nutrients and oxygen to follicles from these earliest stages, including primordial and primary follicles, depends on the vasculature in the ovarian stroma (Fraser \& Wulff 2001). As the primary follicle develops to its next stage, that of the secondary follicle, the differentiation of stromal cells into theca cells results in the addition of cellular layers to the follicle and allows it to develop its own extra-follicular vasculature, essential for follicular growth from this point onward (Robinson et al. 2009). The vascular network of the follicle is confined to the theca layer by the basement membrane that separates the theca and granulosa layers. Thus, the granulosa cell layer remains avascular until ovulation (Fraser \& Wulff 2001, Tamanini \& De Ambrogi 2004, Fraser 2006).

The establishment of a vascular network in the theca layer is an essential event in the development of preantral follicles. In the sow and marmoset, vascularity appears in the theca layer from secondary follicles and increases gradually during antral follicle development (Wulff et al. 2001, Martelli et al. 2009). In the sow, this results in a high correlation between the vascular area of healthy preantral follicles and the proliferation indices of granulosa and theca cells (Martelli et al. 2009). The prevailing view is that dynamic angiogenesis is essential for the attainment of follicle dominance and thus survival (Reynolds \& Redmer 1998, Plendl 2000). In the rhesus monkey, the percentage of the theca layer occupied by blood vessels in the dominant follicles is greater than that in smaller antral follicles (Zeleznik et al. 1981). As a result of their increased vascularity, dominant follicles are believed to be exposed to more gonadotropins from circulation than are nondominant antral follicles (McNatty et al. 1981). In follicles that do not persist to later stages of development, reduction of endothelial cell proliferation in the theca layer is associated with atresia (Greenwald 1989). Several reports have confirmed this finding in a number of species, including cattle and pigs (Mattioli et al. 2001, Jiang et al. 2003). In the marmoset, the vasculature of atretic tertiary follicles is less extensive compared with the vasculature of healthy late secondary or healthy tertiary follicles (Wulff et al. 2001). Thus, it has been suggested that the decrease in vascularization is a cause or a consequence of atresia, perhaps because dying follicles fail to produce the factors needed to support vasculature.

\section{Ovulation}

Follicular vasculature is a dynamic aspect of the ovulatory process, with vascular changes contributing to follicular rupture and luteinization. The importance of angiogenesis and vascular changes during ovulation has been recently reviewed (Duffy et al. 2019). After induction of ovulation with human chorionic gonadotropin (hCG), endothelial cells are restricted to the theca layer for a period of $12 \mathrm{~h}$ in both humans and cynomolgus macaques. However, as ovulation approaches, between 18 and $36 \mathrm{~h}$ after the ovulatory signal, endothelial cells invade into the granulosa cell layer (Trau et al. 2015, 2016, Kim et al. 2017). There is evidence that blocking some angiogenic factors partially or fully blocks ovulation in monkeys (Kim et al. 2014, Bender et al. 2018). A similar phenomenon was observed in mice (Kizuka et al. 2012). In contrast, in sows, a distinct increase in angiogenesis was observed during the periovulatory period but without invasion of vasculature into the granulosa layer (Martelli et al. 2009). Together, this evidence suggests that the LH surge induces angiogenic changes required for ovulation.

\section{Regulation of angiogenesis during follicle development and ovulation and the role of ONRs}

The factors that regulate angiogenesis during follicle development and ovulation have been reviewed elsewhere (Robinson et al. 2009, Rizov et al. 2017, Devesa \& Caicedo 2019, Duffy et al. 2019). In these reviews and in the reports of others, the consensus view is that the principal players in follicular and ovulatory angiogenesis are VEGFA, PGF, VEGFC, VEGFD, PGE2, ANGPT1, ANGPT2, and THBS1. 


\section{VEGFA system}

VEGFA is a member of a protein family that also includes VEGFB, VEGFC, VEGFD and PGF (Apte et al. 2019). Among these, VEGFA is the most studied, both in the ovary and in other tissues. The importance of VEGFA in the regulation of physiological and pathological angiogenesis has been widely discussed (see recent review by Apte et al. 2019 for detail). Several isoforms produced by alternative splicing of immature VEGFA mRNA have been identified in humans and other mammals (Fig. 2). The isoforms are denoted as VEGFxxx where $x x x$ represents the length of the protein in the number of amino acids. In addition to these isoforms of varying sizes, alternative splicing of the proximal or distal region of exon 8 yields two groups of isoforms of equal size. If splicing occurs at the proximal splice site of exon 8, it will produce isoforms designated as VEGFxxxa or simply VEGFxxx, but if splicing is at the distal splice site of exon 8, the VEGFxxxb isoforms are produced (Harper \& Bates 2008, Nowak et al. 2008).

The biological effects of VEGFA isoforms are mediated by two tyrosine kinase receptors, namely VEGFR1 (FLT1) and VEGFR2 (FLK1 or KDR). These two receptors seem to regulate partially distinct subsets of downstream effects. Effects of VEGFxxx isoforms on proliferation, survival, vascular permeability, and cellular migration are mediated by VEGFR2, whereas effects of VEGFxxx through VEGFR1 are limited to the stimulation of vascular permeability and cellular migration (Rosales-Torres \& Guzmán-Sánchez 2011, Shibuya 2015). Additionally, alternative splicing of the immature mRNA of these membrane receptors results in two different soluble receptors, namely soluble VEGFR1 and soluble VEGFR2 (Stevens \& Oltean 2019). These soluble receptors lack the transmembrane and intracellular domains, but their ligand-binding domain is preserved (Stevens \& Oltean 2019). This suggests that the soluble VEGFA receptors negatively regulate the biological effects of VEGFxxx. Together, these isoforms have been designated as the VEGFA system.

\section{VEGFA system in follicular growth and development}

Bovine granulosa cells express total VEGFA mRNA more abundantly than do theca cells (Ortega-Serrano et al. 2016), and mRNA coding for VEGF120 and VEGF164 isoforms is increased in bovine granulosa cells of healthy ovarian follicles compared to granulosa cells of atretic follicles (Zamora-Gutiérrez et al. 2019). Similarly, in cows, there is a linear increase in the VEGFA mRNA expression and VEGFA protein concentration in follicular fluid concomitant with the increase in estradiol concentration and follicle size (Berisha et al. 2000, 2016a). In nonhuman primates, inhibition of

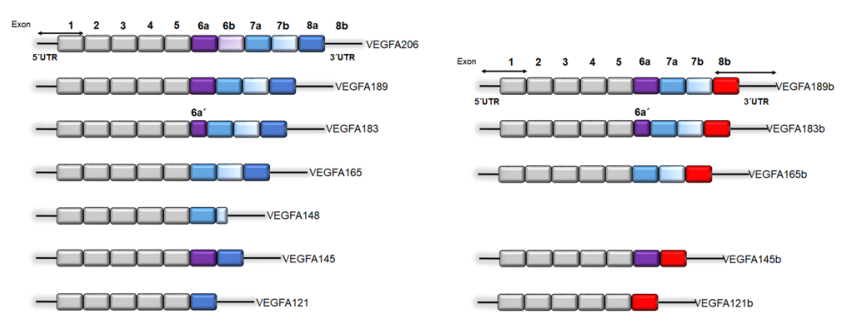

Figure 2 VEGFA isoforms generated by alternative-splicing of immature VEGFA mRNA. In addition to the variation in sizes (number of amino acids), alternative splicing of the proximal or distal region of exon 8 yields two groups of isoforms of equal size but antagonistic in function. If splicing occurs at the proximal splice site of exon 8 , it will produce isoforms designated as VEGFxxxa or simply VEGFxxx (angiogenic isoforms), but if splicing is at the distal-site of exon 8, the VEGFxxxb isoforms (antiangiogenic isoforms) are produced (modified from Harper \& Bates 2008).

VEGFA action in the follicle reduces preantral and antral follicular growth by reducing angiogenesis (Wulff et al. 2002, Taylor et al. 2007). Additionally, injection of a transcriptionally active fragment of the VEGFA gene into the ovarian medulla in prepubertal miniature pigs, together with eCG treatment, increases ovarian weight and the number of large follicles, when compared to ovaries treated with eCG alone (Shimizu et al. 2003). Together, these results suggest that VEGFA is involved in the angiogenic process that is necessary for the selection of the preovulatory follicle or follicles.

VEGFA isoforms also control angiogenesis during ovulation. In cynomolgus macaques, mRNA abundance of VEGF165 and VEGF121 in preovulatory follicles, as well as the follicular fluid concentrations of VEGFA protein, increase at $12 \mathrm{~h}$ after hCG treatment, after which the mRNA decreases and the protein content ceases to change (Bender et al. 2018). As with follicular development, inhibition of VEGFA during the ovulation period compromises ovulation (Bender et al. 2019).

\section{Antiangiogenic VEGFA forms}

The VEGFA system has antiangiogenic members. While VEGFxxx are angiogenic isoforms that promote proliferation, migration, and survival of endothelial cells, VEGFxxxb isoforms have only a weak angiogenic effect and are considered antiangiogenic (Guzmán et al. 2015). VEGF165b binds to either VEGFR1 or VEGFR2 and reduces tyrosine phosphorylation of these receptors (Nowak et al. 2008), leading to a reduction of downstream effects. In diabetic retinopathy, a lower ratio of VEGF165b to total VEGFA is associated with increased angiogenesis during disease progression (Jiang et al. 2020). Similarly, when human umbilical vein endothelial cells (HUVEC) are treated with either 
VEGF121b or VEGF165b, they proliferate less robustly than cells treated with VEGF165a do. In summary, the data indicate that a greater abundance of the VEGFxxxb isoforms is a mechanism that inhibits angiogenesis.

In the ovary, overexpression of VEGF165b led to reduced fertility and increased follicular atresia in mice (Qiu et al. 2012). However, the VEGF120b isoform is more abundant in healthy bovine follicles than in atretic follicles (Zamora-Gutiérrez et al. 2019), suggesting that individual VEGFxxxb isoforms have varying ovarian effects.

VEGFR1 and soluble VEGFA receptors also are antiangiogenic factors. VEGFR1 is less likely to be phosphorylated in response to VEGFA binding as compared to VEGFR2 (Waltenberger et al. 1994). This results in attenuated VEGFA-mediated angiogenesis (Boonyaprakob et al. 2003). Cancer therapy studies have shown that an increase in the expression of soluble VEGFR1 (Owen et al. 2012) or soluble VEGFR2 (Schmitz et al. 2006, Szentirmai et al. 2008) reduces tumor cell proliferation and increases apoptosis (Szentirmai et al. 2008), which is associated with a reduction in tumor angiogenesis. In human breast cancer, the expression of soluble VEGFR1 improves the disease prognosis, because the soluble form reduces tumor growth and vascularization (Toi et al. 2002).

In the context of bovine ovarian function, a reduction in the expression of solubleVEGFR1 and solubleVEGFR2 may facilitate VEGF action to increase angiogenesis during follicle selection (Ortega-Serrano et al. 2016). In addition, mRNA for soluble VEGFR2 was found in greater abundance in atretic bovine follicles compared to healthy follicles (Zamora-Gutiérrez et al. 2019). Additionally, antral follicle growth is characterized by a reduction in the oxygen levels within the follicle in several species, including human and cow (Lim et al. 2021), and it is well known that hypoxia is necessary for normal granulosa cell function (Zeebaree et al. 2018). Recently, a reduction in the mRNA of soluble VEGFR1 and soluble VEGFR2 in bovine granulosa cells cultured under hypoxic conditions has been demonstrated (Hernández-Morales et al. 2021), suggesting that hypoxia may promote angiogenesis by reducing the abundance of soluble VEGFRs.

\section{ONRs regulate VEGFA system members}

The regulation of the expression and function of the VEGFA system members depends on several factors, including hormones, growth factors, and oxygen availability. There is evidence from studies of angiogenesis in organs other than the ovary to suggest that ONRs may regulate proteins of the VEGFA system and thus control angiogenesis (Table 1). These ONRs include NR0B1, NR1D1, NR1F1, NR1F3, NR2C2, NR2F2 and all members of the NR3A and NR4A and NR5A subfamilies.

\section{Nrob1}

Deletion of NROB1 in the testis causes disordered neovascularization and an increase in the concentration of VEGFA protein in the testis (Kang et al. 2015), suggesting that NR0B1 may reduce the synthesis of VEGFA to inhibit excess vasculature development. The expression of NR0B1 has also been reported in human (Sato et al. 2003, Nakamura et al. 2009), mouse (Salmon et al. 2005) and rat (Saxena et al. 2007) granulosa cells, as well as in bovine theca cells (Murayama et al. 2008). The main function of NROB1 in the ovary is to reduce steroid synthesis by inhibiting the ability of NR5A1 and NR5A2 to induce transcription of important steroidogenic genes, including StAR and CYP17A1 (Tajima et al. 2003, Saxena et al. 2007, Murayama et al. 2008, Shimizu et al. 2009, Bertolin et al. 2010). Nevertheless, no evidence yet exists to implicate this ONR in the regulation of ovarian vasculature, and females lacking NROB1 are fertile (Yu et al. 1998). This suggests that its absence does not sufficiently impair angiogenesis in the ovaries of these individuals.

\section{ONR1 family members}

NR1D1 also regulates VEGFA expression. In colorectal cancer cells, NR1D1 binds to an NR1F1-responsive element (RORE) in the VEGFA gene promoter, resulting in increased VEGFA synthesis (Burgermeister et al. 2019). NR1D1 is expressed in human (Jiang et al. 2020) and rat (Chen et al. 2013) granulosa cells. Murine females lacking NR1D1 are subfertile, with fewer fertile matings and smaller litters relative to their WT counterparts (Chomez et al. 2000, Preitner et al. 2002). In rat granulosa cells, NR1D1 is regulated by FSH (Chen et al. 2012). The use of a pharmacological agonist to enhance the activity of this ONR promotes the expression of StAR (Chen et al. 2012). This evidence indicates that inadequate steroid hormone synthesis contributes to the phenotype of subfertility observed in females lacking NR1D1. Moreover, if this ONR also regulates VEGFA in the ovary, the subfertility could also potentially be associated with deficient angiogenesis. These concepts remain to be investigated.

NR1F1 and NR1F3 regulate angiogenesis via the VEGFA system in several contexts, including retinopathy (Sun et al. 2017), ischemia (Besnard et al. 2001), cancer (Xiao et al. 2015), tissue repair (Ling et al. 2017), and testicular development (Sayed et al. 2019). Insufficient expression or inhibition of NR1F1 or NR1F3 reduces VEGFA expression and angiogenesis under conditions of reduced oxygen concentration (Sun et al. 2015, Suyama et al. 2016) and this varies with cell type (Talia et al. 2016). In contrast, deficient expression of NR1F1 is associated with increased VEGFA synthesis in murine testes (Sayed et al. 2019). There is a similar low level of NR1F1 expression in the murine hindlimb ischemia model, 
in which there is a high rate of angiogenesis without an accompanying change in protein concentration of VEGFA (Besnard et al. 2001). In colon cancer cells, pharmacological activation of NR1F1 reduces VEGFA mRNA expression (Xiao et al. 2015). This suggests that the effect of the NR1F family, and perhaps NR1F1 in particular, on angiogenesis is highly dependent upon cell type.

NR1F1 is expressed in cumulus cells of the rat and sheep ovary (Coelho et al. 2015, Fang et al. 2019). In ovine cumulus cells in culture, melatonin treatment reduces oxidative stress via induction of NR1F1 (Fang et al. 2019). Effects of NR1F1 on ovarian angiogenesis or regulation of VEGFA in the ovary have yet to be reported.

\section{Subfamily ONR2}

ONRs of subfamily 2, most notably NR2C2 and NR2F2, are involved in regulating angiogenesis via the VEGFA system. In prostate cancer cells, inhibition of NR2C2 reduced the mRNA for both HIF1a and VEGFA, whereas overexpression of this ONR increased the abundance of both (Hu et al. 2020). Female mice with germline deletion of NR2C2 displayed subfertility, irregular estrous cycles, impaired response to superovulation, and increased follicular atresia. (Chen et al. 2008). This is due, in large part, to the ability of NR2C2 to regulate $\mathrm{FSH}$ and $\mathrm{LH}$ receptors in granulosa cells (Zhang \& Dufau 2001). These gonadotropin receptors are upstream to key steroidogenic enzymes, such as StAR and CYP11A1, which are also dysregulated in mice lacking NR2C2 (Chen et al. 2008). The evidence that NR2C2 is a regulator of HIF1a and VEGFA (Hu et al. 2020) suggests that inadequate ovarian vascular development could explain, in part, the phenotype of increased follicular atresia in NR2C2 knockout mice. Further investigation is needed to delineate this relationship.

NR2F2 is essential for angiogenesis and cardiovascular development. This has been illustrated by the death of NR2F2-null embryos due to defects in these processes during early embryonic development (Pereira et al. 1999). Although the results of some of these studies are conflicting, the importance of NR2F2 as a regulator of angiogenesis through regulation of VEGFA expression has been verified (Zhou et al. 2000, Lin et al. 2011, Xu et al. 2015). In marrow-derived mesenchymal stem cells, astrocytes, and prostate adenocarcinoma, NR2F2 seems to positively regulate VEGFA (Li et al. 2013, Zhu et al. 2016, Lilis et al. 2018). In contrast, conditional deletion of NR2F2 in pancreatic islet tumors resulted in an increase in the mRNA for VEGFA (Qin et al. 2010a). When Polvani et al. (2014) silenced NR2F2, there was no discernable change in VEGFA mRNA. These conflicting results might be explained by the observation that NR2F2 binds to different regions of the promoter of VEGFA to regulate its transcription in different types of human cancer cells (Erdos \& Bálint 2019).
NR2F2 may also regulate other members of the VEGFA system. Conditional deletion of NR2F2 is associated with a reduction in tumor angiogenesis and malignancy, seemingly through an increase in VEGFR1 and soluble VEGFR1 (Qin et al. 2010b). This suggests that NR2F2 may regulate not only VEGFA ligands but also VEGFA receptors, to favor a proangiogenic environment in the tissues.

NR2F1 and NR2F2 are expressed in murine (Xing et al. 2002, Petit et al. 2007) and bovine (Wehrenberg et al. 1992, Murayama et al. 2008) theca and granulosa cells, as well as in human follicles (Sato et al. 2003). All three NR2F receptors, NR2F1, NR2F2, and NR2F6, reduce gonadotropin receptor expression (Zhang \& Dufau 2001, 2003). Despite this negative effect on gonadotropin receptor expression, there seems to be a role for NR2F2 in promoting the expression of steroidogenic genes. Heterozygote females lacking one allele of NR2F2 $\left(\mathrm{NR} 2 \mathrm{~F} 2^{+-}\right.$) have reduced ovarian mRNA expression of NR2F2 and reduced mRNA expression of CYP11A1, HSD3B1 and StAR, relative to WT mice. Additionally, the corpora lutea of $\mathrm{NR} 2 \mathrm{~F}^{+/-}$females have vascular defects (Takamoto et al. 2005). This suggests a potential role for NR2F2 in the regulation of luteal angiogenesis. Given that some of the findings regarding the role of NR2F2 in both VEGFA expression and ovarian function are contradictory, further investigation is required to determine the effects of NR2F2 in the regulation of VEGFA in the ovary.

\section{The ONRs of subfamily 3}

NR3B1 and NR3B3, but not NR3B2, regulate angiogenesis by controlling the expression of VEGFA system members. This evidence mostly comes from studies in human endothelial cells and cancer. In several lines of human endothelial cells, inhibition of NR3B1 with an inverse agonist or via gene silencing reduces angiogenic proliferation, migration, and tubelike structure formation (Zhang et al. 2015, Li et al. 2016, Matsushima et al. 2016, Wu et al. 2017). In human endometrial and ovarian cancer cell lines, the use of an inverse agonist of NR3B1 or NR3B1 siRNA reduces tumor weight, the proliferation of tumor cells and tumor microvascular density (Luo et al. 2009, Zhang et al. 2015, Matsushima et al. 2016, Kokabu et al. 2019). The mechanisms by which inhibition of NR3B1 reduces angiogenesis in both endothelial and cancer cells include a reduction in mRNA and protein concentrations of VEGFA (Luo et al. 2009, Zhang et al. 2015, Li et al. 2016, Matsushima et al. 2016, Wu et al. 2017) and a reduction in the kinase activity of VEGFR 1 (Li et al. 2016). Although the majority of the evidence suggests a proangiogenic role for NR3B1, in one study, the deletion of NR3B1 in HUVEC resulted in an increase in VEGFR2, accompanied by a reduction in cellular proliferation, along with an increase in migration and 
tube-like formation (Likhite et al. 2019). The increase observed in the expression of VEGFR2 could explain the increase in migration and tube-like formation observed in this study, since this receptor is the principal regulator of the biological effects of VEGFA.

It is well documented that hypoxia, through the HIF system, is the major regulator of VEGFA expression (Tamura et al. 2019). In human cancer cells, there is an electrostatic interaction between $\mathrm{NR} 3 \mathrm{Bs}$ and the functional heterodimer HIF1 $\alpha / \mathrm{HIF} 1 \beta$, but not with either monomer (HIF1 $\alpha$ or HIF1 $\beta$ ) alone (Ao et al. 2008). Interestingly, pharmacological inhibition of NR3Bs in human cancer cells blocks the increase in VEGFA expression induced by hypoxia (Ao et al. 2008). In contrast in prostate cancer cells, NR3B1 may bind to HIF1 $\alpha$ alone to promote the expression of VEGFA under hypoxic conditions (Zou et al. 2014). Although it seems clear that NR3B1 acts as a cofactor to HIF1 $\alpha$ to regulate transcription of VEGFA, there is another line of evidence showing that this ONR binds to a coactivator of another nuclear receptor, PGC-1a (peroxisome-proliferatoractivated receptor-c coactivator-1a), to promote VEGFA expression via an HIF1 $\alpha$-independent pathway (Arany et al. 2008). In primary embryonic fibroblasts, overexpression of PGC-1a induced VEGFA expression in cells from WT mice but not those from NR3B1 ${ }^{-1-}$ mice (Arany et al. 2008). In agreement with these results, induction of VEGFA expression with the flavonoid baicalin in human glioblastoma cells is inhibited by silencing of NR3B1, PGC-1a, or both (Zhang et al. 2011b). Arany et al. (2008) suggested that the first intron of the VEGFA gene has conserved NR3B1-binding sites that are additionally coactivated by PGC-1a thereby eliciting robust induction of VEGFA transcription.

As with NR3B1, the role of NR3B3 in the regulation of vascular development has been documented. In diabetic $\mathrm{db} / \mathrm{db}$ mice, which have a deletion in the leptin receptor gene, loss of muscular vasculature is prevented by overexpression of NR3B3 in skeletal muscle (Badin et al. 2016). In this model, NR3B3 overexpression increases mRNA of total VEGFA (Fan et al. 2018a,b) and VEGFA isoforms 121, 165 and 180, (Badin et al. 2016). Likewise, inhibition of NR3B3 reduces angiogenesis stimulated by IL- 6 in vivo, and silencing of this ONR also reduces VEGFA protein concentrations in chondrocytes treated with the interleukin IL-6 (Zhao et al. 2019). NR3B3 binds to the estrogen receptor response element (ERRE; AGGTCA) in the VEGFA promoter of the rat, indicating that this site may mediate NR3B3-induced VEGFA transcription (Zhao et al. 2019).

Despite the clear evidence that ONRs of subfamily 3 regulate VEGFA expression and angiogenesis, these ONRs seem not to be vital to ovarian function, although just a few reports are available in this regard. The presence and abundance of NR3B2 and NR3B3 mRNA and protein have been quantified in sow cumulus granulosa cells in vitro (Kempisty et al. 2015). In human granulosa cells, mRNA coding for NR3B3 has also been reported (Amar et al. 2020). Female mice lacking NR3B1 $\left(\mathrm{NR} 3 \mathrm{~B}^{-/-}\right)$have no detectable ovarian abnormalities and are fertile (Luo et al. 2003). In another study, germline deletion of NR3B2 in the embryonic gonad resulted in a reduction in the number of germ cells in both adult males and females (Mitsunaga et al. 2004). Additionally, adult females lacking this receptor did not become pregnant, in spite of apparently phenotypically normal oocytes in their ovaries (Mitsunaga et al. 2004). Thus, it seems that ONRs of subfamily 3 are important for the regulation of VEGFA expression, but it is not yet known whether these effects are obligatory at the level of the ovary.

\section{The ONR4 family}

The importance of the NR4A subfamily as transcription factors involved in the control of angiogenesis is well documented (Mohan et al. 2012, Peng et al. 2019, Ye et al. 2019). The effects may be reciprocal, as several lines of evidence from in vitro and in vivo angiogenic models show that VEGFA and other angiogenic factors increase mRNA and protein concentrations of NR4A1, NR4A2, and NR4A3 (Liu et al. 2003, Rius et al. 2006, Zeng et al. 2006, Martorell et al. 2009, Zhao et al. 2011, 2014, Qin et al. 2013, Zhou et al. 2016). To date, direct or reciprocal angiogenic effects have not yet been evaluated at the ovarian level. Loss of NR4A1 and NR4A3 inhibits proliferation and migration in HUVEC, even in the presence of VEGFA (Rius et al. 2006, Zhao et al. 2011, Chen et al. 2020). These results suggest that the effect of NR4A1 on angiogenesis results from an impaired ability of cells to respond to VEGFA, even when VEGFA is present in the system. HUVEC cells transfected to overexpress NR4A1 have a proliferation rate that is similar to non-transfected cells that have been treated with VEGF165 added to the culture media, and both proliferate at a greater rate than controls (Zeng et al. 2006). Moreover, VEGFA treatment has no additional effect on proliferation in transfected cells that are already overexpressing NR4A1 (Zeng et al. 2006).

The germline deletion of NR4A1 does not disrupt reproductive function (Lee et al. 1995, Cheng et al. 1997), whereas global knockout of NR4A2 or NR4A3 results in the death of offspring prior to or immediately after birth (Zetterström et al. 1997, Ponnio et al. 2002, DeYoung et al. 2003). Additionally, ONRs of the NR4A subfamily have been implicated in ovulation (Carletti \& Christenson 2009) and steroidogenesis (Wu et al. 2015). Other studies have demonstrated the involvement of these ONRs in the actions of fibroblast growth factors on bovine granulosa cell function (Jiang et al. 2011, 2013, Jiang \& Price 2012, Han et al. 2017) and as 
immediate-early genes in response to the $\mathrm{LH}$ surge (Hughes \& Murphy 2021). The rapid induction of NR4A1 and NR4A2 causes the ovarian shift from estradiol to progesterone synthesis in response to the ovulatory signal, via suppression of CYP19A1 (Wu et al. 2005). Additionally, NR4A1 appears to modulate the effects of gonadotropins on antral follicle development (Segers et al. 2012) and inhibin synthesis and secretion (He et al. 2013). This receptor also negatively regulates the excessive follicular growth in hyperandrogenism models (Xue et al. 2012). Deletion of NR4A1 in mice reduces mRNA of both androgen receptor and kit ligand, two important molecules involved in follicular growth and follicle activation, respectively (Dai et al. 2012). The importance of NR4A1, 2, and 3 in angiogenesis, particularly their regulation of the angiogenic function of VEGFA, and their evident role in ovulation lead to the hypothesis that these receptors are involved in regulating angiogenesis during ovulation.

\section{SF-1 and $L R H-1$}

NR5A1 and NR5A2 have also been implicated in the regulation of VEGFA and in angiogenesis. Lalli et al. (2013) suggested that NR5A1 regulates angiogenesis during adrenal gland development, as well as in adrenocortical tumors. Interestingly, during maternal recognition of pregnancy in the sow, luteal expression of both NR5A1 and of VEGFA increases, accompanied by a reduction in HIF1a (Przygrodzka et al. 2016). It has been well-documented that NR5A1 is important for ovarian steroidogenesis (Meinsohn et al. 2019), so this ONR may regulate angiogenesis through its effects on steroid synthesis (Karizbodagh et al. 2017, Trenti et al. 2018). However, the extent to which this occurs is yet to be determined.

NR5A2 regulates angiogenesis in tumors. Overexpression of NR5A2 in pancreatic cells increases cell proliferation, tumor growth, and angiogenesis (Lin et al. 2014a,b). NR5A2 is also a regulator of angiogenesis in the ovary. Gene ontology analysis from a recent RNAseq study showed that NR5A2 regulates multiple pathways during the ovulation process, including angiogenesis and cellular migration (Bianco et al. 2019). These authors showed that at least 80 genes related to blood vessel development are regulated by loss of NR5A2, of which 14, including VEGFA, increase in granulosa cells after the LH surge in control mice but fail to change when NR5A2 is depleted in granulosa cells (Bianco et al. 2019). Similarly, conditional deletion of NR5A2 in granulosa cells of antral follicles (with Cyp19A1-cre) reduces the mRNA of VEGFA at 12, 18 and $24 \mathrm{~h}$ after LH surge (Bertolin et al. 2014). These data suggest that NR5A2 is an essential regulator of angiogenesis that occurs in response to the ovulatory LH signal.

\section{Other members of the VEGF family}

The role of the VEGF family members PGF, VEGFC and VEGFD in angiogenesis has been explored in several tissues, including the ovary, under both physiological and pathological conditions (Vrachnis et al. 2013, Nejabat et al. 2017, Melincovici et al. 2018, Wei \& Zhao 2020). In cynomolgus macaques, PGF mRNA expression and protein concentration in follicular fluid are greater at $36 \mathrm{~h}$ after hCG treatment compared to pretreatment and $12 \mathrm{~h}$ after hCG (Bender et al. 2018). Interestingly, injection of ovulatory follicles with antibodies directed against PGF-reduced angiogenesis of these follicles and compromised ovulation (Bender et al. 2018). This suggests that PGF is necessary for vascular changes during ovulation. VEGFC and VEGFD are principally implicated in lymphangiogenesis (Melincovici et al. 2018), but they have been also shown to regulate vascular changes during ovulation. In adult female cynomolgus monkeys, the LH surge did not affect mRNA expression of VEGFC or D in granulosa cells (Kim et al. 2017). In contrast, in the mouse, LH surge increased the mRNA expression of VEGFC and D in granulosa cells (Brown et al. 2010). With respect to protein expression, Kim et al. (2017) showed an increase in VEGFC and D concentration at $24 \mathrm{~h}$ after hCG treatment. These results suggest that either a transcriptional or posttranscriptional effect of LH on these molecules exists, depending on the species. Both VEGFC and D promote migration of monkey ovarian microvascular endothelial cells in vitro, but only VEGFD promotes proliferation (Kim et al. 2017).

Some ONRs may regulate these members of the VEGF family. Inhibition of NR1F3 alone or both NR1F1 and NR1F3 reduced PGF $m R N A$ and protein in oxygeninduced retinopathy models (Talia et al. 2016). A reduction in tumor angiogenesis and malignancy due to silencing of NR2F2 is associated with the reduction in mRNA expression of VEGFC (Polvani et al. 2014). PGF may also regulate the expression of ONRs. In human trophoblast cells, NR4A1 increased PGF mRNA and protein abundance ( $\mathrm{Li}$ et al. 2019). Nevertheless, no reciprocal effect has been confirmed; and, in HUVEC, PGF treatment affected neither NR4A1 mRNA nor NR4A1 protein (Zeng et al 2006).

\section{Interactions between ONRs and PGE2 in angiogenic events}

The prostaglandin, PGE2, modulates angiogenesis in tumor growth (Hashemi Goradel et al. 2019), and because PGE2 is necessary for ovulation (Lim et al. 1997, Davis et al. 1999, Hizaki et al. 1999), its role in the regulation of ovulatory angiogenesis has recently drawn attention (Duffy et al. 2019). Inhibition of PGE2 synthesis resulted in inhibition of LH-stimulated angiogenesis (Trau et al. 2015) and blocked ovulation (Kim et al. 2014). In non-human primates, endothelial cells express PGE2 
receptors, and the increase in PGE2 synthesis after the LH surge is accompanied by an increase in angiogenesis (Trau et al. 2015). This suggests a direct effect of PGE2 on ovarian endothelial cells. In vitro, PGE2 stimulates endothelial cell migration in a similar way to VEGFA but does not alter endothelial cell proliferation or survival (Trau et al. 2015, 2016). Thus, it is likely that PGE2 promotes endothelial cell migration from theca layer to the granulosa compartment during ovulation.

Three ONRs, NR1D1, NR5A1, and NR5A2 are associated with PGE2 synthesis. In rat endometrial stromal cells, NR1D1 binds to a RORE in the promoter of prostaglandin $\mathrm{G} / \mathrm{H}$ synthase 2 (PTGS2 or COX2) to inhibit its transcription, and thus reduces PGE2 synthesis (Isayama etal. 2015). In preadipocytes, silencing of NR5A1 reduces the secretion of PGE2, whereas overexpression increases it (Wang et al. 2019). In mouse granulosa cells, conditional deletion of NR5A2 in granulosa cells by Amhr-Cre recombinase reduces PTGS2 mRNA at 4 and $12 \mathrm{~h}$ after ovulatory signal (Duggavathi et al. 2008).

In the reciprocal sense, PGE2 is also a regulator of several ONRs. It has been shown that PGE2 activates NR1F1 in colorectal cancer cells via PKCa-dependent phosphorylation (Shin et al. 2014). PGE2 regulates the transcription and activity of NR3B1 to regulate steroidogenesis in prostate stromal cells (Miao et al. 2010, Ning et al. 2014). In the culture of hematopoietic stem cells or dental cementoblast cells, PGE2 treatment increased mRNA for NR4A1 (Moldovan et al. 2009, Land et al. 2015).

Overall, these results suggest that, among the ONRs, NR5A2 is necessary for PGE2 synthesis and, given its additional role in the regulation of VEGFA, it is reasonable to hypothesize that NR5A2 could also be necessary for the angiogenesis that accompanies ovulation. In addition, NR1D1 and NR5A1 also may promote PGE2 synthesis and function to mediate angiogenesis during ovulation, in addition to direct effects on VEGFA system members.

\section{Angiopoietin and ONR interactions}

Angiopoietins are essential for angiogenesis. In addition to their role in controlling the proliferation and survival of endothelial cells, they regulate the remodeling and maturation of blood vessels (Fagiani \& Christofori 2013, Gillen et al. 2019). Their regulation is complex as ANGPT1 is the natural agonist of the TIE2 receptor, whereas ANGPT2 is an antagonist of the same receptor (Isidori et al. 2016). In the bovine follicle, there is no change in the mRNA expression of ANGPT1 with an increase in follicular size and estradiol concentration, but there is a reduction in the mRNA expression of ANGPT2 (Hayashi et al. 2004). During ovulation in cows and rhesus monkeys, the mRNA for ANGPT1 gradually increases, while the mRNA coding for ANGPT2 does not change (Hazzard et al. 1999, Shimizu et al. 2007). In these studies, the ratio of ANGPT2 to ANGPT1 declined linearly from the beginning of the ovulatory signal to follicle rupture. In rats, the pattern of mRNA expression of angiopoietins differs from that in cows and macaques. In this species, mRNA abundance of ANGPT1 did not change between 0 and $24 \mathrm{~h}$ after hCG treatment, whereas ANGPT2 increased at 6 and $12 \mathrm{~h}$ after hCG, as compared with $0 \mathrm{~h}$, after which it declined (Miyabayashi et al. 2005). It is important to note that even though these authors do not report the ratio of ANGPT2/ANGPT1, their data indicate that this ratio declined between 6 and $24 \mathrm{~h}$ after hCG, consistent with observations in cows. Together, these data indicate that the abundance of ANGPT2 relative to ANGPT1 is a likely modulator of angiogenetic potential in the ovary as in other tissues (Yu \& Ye 2020). Indeed, an increase in the ratio of ANGPT2 to ANGPT1 is associated with the onset of blood vessel regression and atresia in antral follicles (Hayashi et al. 2003), whereas a reduction in this ratio seems to be necessary for angiogenesis during ovulation (Miyabayashi et al. 2005, Shimizu et al. 2007).

NR3B3 and NR5A1 are the only ONRs that have been reported to regulate angiopoietins. In diabetic $\mathrm{db} / \mathrm{db}$ mice, loss of muscle vasculature is prevented by overexpression of NR3B3 in skeletal muscle. In this model, NR3B3 overexpression increases ANGPT1 and ANGPT2 (Badin et al. 2016). With respect to NR5A1, Ferraz-de-Souza et al. (2011) identified a 1.1-kb SF-1binding region in the ANGPT2 promoter and confirmed that NR5A1 activates transcription of this gene in human adrenocortical tumor cells. As with the VEGF family, angiopoietins are regulators of NR4A1 mRNA and protein concentrations in HUVEC, but this effect is weak compared with that of VEGFA (Ismail et al. 2012).

\section{THBS1 and follicular growth and ovulation}

THBS1 was the first antiangiogenic protein identified (Good et al. 1990). THBS1 inhibits endothelial cell migration, proliferation, and survival. This molecule also induces endothelial cell apoptosis and counteracts the activity of angiogenic factors, including VEGFA (Lawler \& Lawler 2012). The role of THBS1 in ovarian angiogenesis has been reviewed recently (Farberov et al. 2019). Mice lacking the THBS1 receptor, CD36, develop many antral follicles, but they are unable to ovulate (Osz et al. 2014). In bovine ovarian follicles, the mRNA expression of THBS1 in granulosa cells (Berisha et al. 2016b) and the protein concentration of THBS1 in follicular fluid and granulosa cells declines linearly with the increase in follicular diameter, and is negatively correlated with the concentration of VEGFA (Greenaway et al. 2005). In marmoset monkeys, the mRNA and protein of THBS1 are significantly increased in atretic tertiary follicles (Thomas et al. 2008), which have fewer blood vessels than do their healthy counterparts. Similarly, in ex vivo culture, addition of THBS1 to culture media of rat follicles dramatically reduces angiogenesis and increases follicular atresia (Garside et al. 2010). 
Although the mechanism by which THBS1 reduces angiogenesis has not been elucidated, Greenaway et al. (2007) suggested that THBS1 binds to VEGFA to prevent VEGF-mediated angiogenesis.

THBS1 has further been implicated in angiogenesis during ovulation. Deletion of CD36 in mice increases vascularization of antral follicles, but they are unable to ovulate and luteinize, which corroborates the concept of an antiangiogenic effect of THBS1 (Osz et al. 2014). Despite this evidence, it has recently been shown that THBS1 has the opposite effect on angiogenesis during ovulation. In cynomolgus macaques, THBS1 mRNA and protein concentrations in granulosa cells of preovulatory follicles increased after the LH surge, reaching the peak just before the expected time of ovulation (Bender et al. 2019). Moreover, in vitro experiments using monkey ovarian microvascular endothelial cells showed that THBS1 promotes angiogenesis. In addition, an intrafollicular injection of an antibody against THBS1 prior to hCG treatment reduced angiogenesis and compromised ovulation (Bender et al. 2019).

THBS1 has several domains that act as angiogenic or antiangiogenic factors. The binding of THBS1 to its receptor, CD36, occurs through type I repeats and blocks angiogenesis. THBS1 binds to another cognate receptor, low density lipoprotein receptor-related protein-1 (LRP1), via $\mathrm{N}$-terminal domain, thereby inducing angiogenesis (Huang et al. 2017). The N-terminus is the major heparin-binding site of THBS1. During the cellular matrix degradation that is characteristic of ovulation, metalloproteinases degrade heparin and release the $\mathrm{N}$-terminus of THBS1 (Huang et al. 2017), potentially explaining the angiogenic effects of THBS1 during this process. Additionally, differential expression of THBS1 receptors across follicle status and ovulation could explain the contrasting effects of this molecule in different stages of ovarian angiogenesis.

\section{THBS1 and ONRs}

Based on existing evidence, it appears that NROB2 regulates THBS1 mRNA, but does not regulate VEGFA, PGF, PGE2 or angiopoietins. In the murine liver, deletion of NROB2 increases the mRNA coding for THBS1 leading to hepatic pathology (Smalling et al. 2013). Evidence for the role of NROB2 in ovarian function is limited. Only one recent study reports that NROB2 is expressed in murine granulosa cells. In these cells, expression was in response to activation of farnesoid-X receptor (Takae et al. 2019).

Other ONRs that regulate thrombospondins are NR1D1, NR3B1, and NR4A2. NR1D1 mediates the effects of carbon monoxide on rat aortic endothelial cell migration, by reducing the expression of THBS1 and thus increasing cellular migration (Li et al. 2014). The mechanism by which inhibition of NR3B1 reduces angiogenesis in both endothelial and cancer cells is through THBS1 (Wu et al. 2017). Finally, in primary
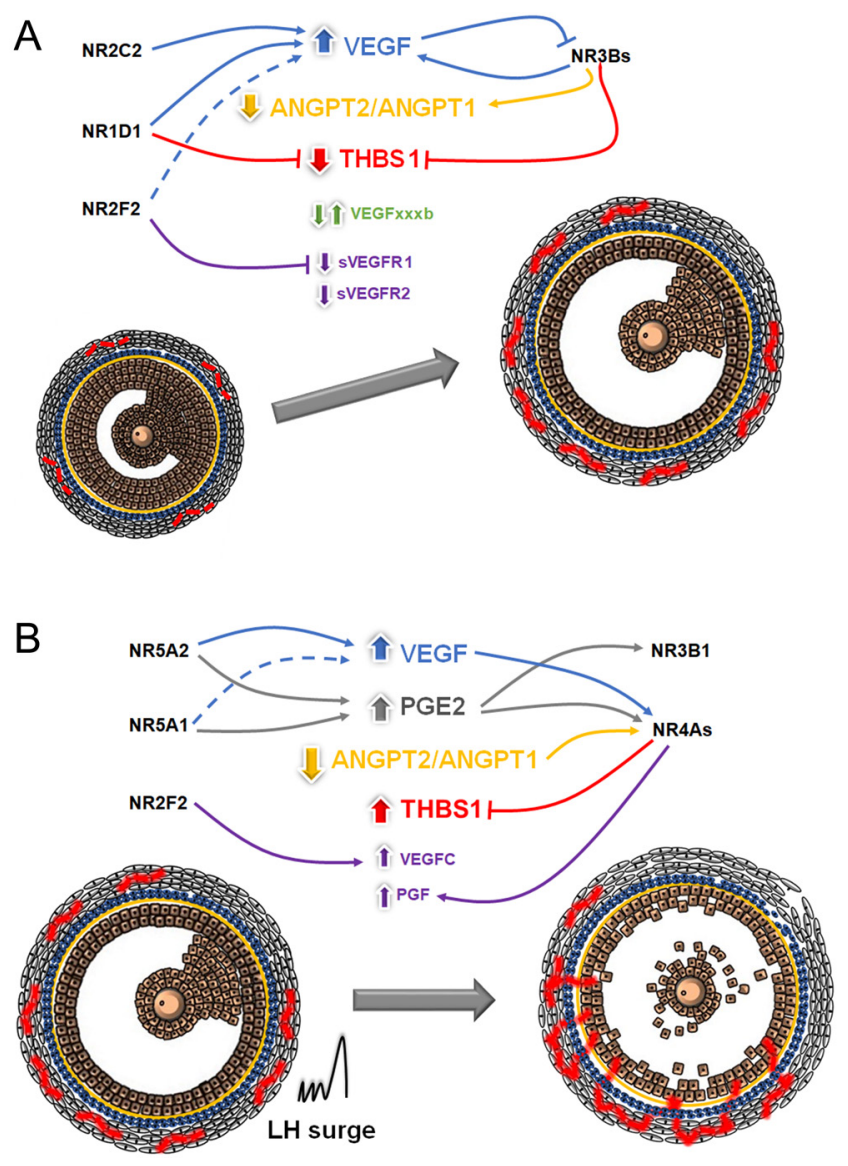

Figure 3 Changes in angiogenesis during antral follicle development (A) and ovulation (B), as well the relationships between orphan nuclear receptors (ONRs) and ovarian angiogenic factors. Putative vascular elements within the theca and granulosa compartments of the follicle are in red. ONRs that regulate or are regulated by specified angiogenic factors are connected by same color of font and arrows. Differences in font size for the ovarian angiogenic factors represent the relative strength and quantity of evidence that supports the role of each factor in each stage of follicular development, with larger font indicating stronger evidence. Arrows with dashed lines represent evidence that is not clear or is contradictory, while solid arrows indicate clear causal relationships.

human fibroblast-like synoviocytes, elevated NR4A2 expression reduces mRNA expression of THBS1 and depletion of NR4A2 increases it. Together with the increase in THBS1, there is a reduction in VEGFA mRNA expression and the ratio of THBS1 to VEGFA increases dramatically, suggesting that deletion of NR4A2 causes an antiangiogenic endocrine milieu in this context (McMorrow et al. 2013).

\section{Conclusion}

The findings reviewed herein indicate that angiogenesis is indispensable for development of antral follicles and also for ovulation. During antral follicular growth, there 
is an increase in VEGFA (mainly VEGFA angiogenic isoforms) together with a reduction in the ANGPT2/ ANGPT1 ratio, THBS1, and soluble VEGF receptors. Together, these changes are expected to promote angiogenesis and development of antral follicles. Integrating our understanding of ONRs that control angiogenesis by regulating ovarian angiogenic factors (Table 1) in tissues other than the ovary with the role of ONRs in follicular growth, the following hypothesis is suggested (Fig. 3). During antral follicle growth NR1D1, NR2C2, NR2F2 and NR3B1 promote VEGFA expression, and reduce THBS1 (NR1D1, NR3B1) and soluble VEGFR1 (NR2F2) to facilitate angiogenesis during this period (Fig. 3A). In contrast, during ovulation (Fig. 3B), angiogenesis is promoted by an increase in VEGFA, VEGFC, PGF, PGE2 and probably also THBS1, accompanied by a reduction in ANGPT2/ANGPT1 ratio. Throughout this period, in addition to the ONRs that are believed to regulate angiogenesis of antral follicles, other ONRs may also play significant roles. These include the NR5As, which promote VEGFA expression and PGE2 synthesis, and NR2F2 and NR4A1, which could upregulate VEGFC and PGF respectively. In addition, the transcription and activity of the NR4As in the ovary could also be regulated by VEGFA, PGE2 and ANGPT1, suggesting that angiogenic factors regulate ONRs and their downstream effects. Together, this suggests that NR2F2, NR3B1, NR4As and NR5As are important for ovulatory angiogenesis (Fig. 3B). In summary, we suggest, based upon this literature review of ONR-regulated angiogenesis throughout the body, that these ONRs play multiple roles in angiogenesis during follicular growth and ovulation.

\section{Declaration of interest}

The authors declare that there is no conflict of interest that could be perceived as prejudicing the impartiality of this review.

\section{Funding}

Funding for $\mathrm{C} \mathrm{H} \mathrm{K} \mathrm{H}$ was provided by a Lalor Foundation Fellowship. Studies of orphan nuclear receptors in the BDM Laboratory are funded by PJT 166020 from the Canadian Institutes of Health Research.

\section{Author contribution statement}

A G conceived the review content and wrote the first draft of the manuscript. $\mathrm{C} \mathrm{H} \mathrm{K} \mathrm{H}$ provided modification and critical feedback on the manuscript. B D M edited the manuscript. All authors approved the manuscript prior to submission.

\section{Acknowledgements}

A G would like to thank the Universidad Autónoma Metropolitana for the Academic Improvement Grant.

\section{References}

Al-Khuzaei S, Broadgate S, Halford S, Jolly JK, Shanks M, Clouston P \& Downes SM 2020 Novel pathogenic sequence variants in NR2E3 and clinical findings in three patients. Genes 11 1288. (https://doi. org/10.3390/genes11111288)

Amar S, Binet A, Téteau O, Desmarchais A, Papillier P, Lacroix MZ, Maillard V, Guérif F \& Elis S 2020 Bisphenol S impaired human granulosa cell steroidogenesis in vitro. International Journal of Molecular Sciences 21 1821. (https://doi.org/10.3390/ijms21051821)

Ao A, Wang H, Kamarajugadda S \& Lu J 2008 Involvement of estrogenrelated receptors in transcriptional response to hypoxia and growth of solid tumors. PNAS 105 7821-7826. (https://doi.org/10.1073/ pnas.0711677105)

Apte RS, Chen DS \& Ferrara N 2019 VEGF in signaling and disease: beyond discovery and development. Cell 176 1248-1264. (https://doi. org/10.1016/j.cell.2019.01.021)

Aranda A \& Pascual A 2001 Nuclear hormone receptors and gene expression. Physiological Reviews 81 1269-1304. (https://doi. org/10.1152/physrev.2001.81.3.1269)

Arany Z, Foo SY, Ma Y, Ruas JL, Bommi-Reddy A, Girnun G, Cooper M, Laznik D, Chinsomboon J, Rangwala SM et al. 2008 HIF-independent regulation of VEGF and angiogenesis by the transcriptional coactivator PGC-1alpha. Nature 451 1008-1012. (https://doi.org/10.1038/ nature06613)

Badin PM, Vila IK, Sopariwala DH, Yadav V, Lorca S, Louche K, Kim ER, Tong Q, Song MS, Moro C et al. 2016 Exercise-like effects by estrogenrelated receptor-gamma in muscle do not prevent insulin resistance in db/db mice. Scientific Reports 6 26442. (https://doi.org/10.1038/ srep26442)

Bender HR, Trau HA \& Duffy DM 2018 Placental growth factor is required for ovulation, luteinization, and angiogenesis in primate ovulatory follicles. Endocrinology 159 710-722. (https://doi.org/10.1210/en.201700739)

Bender HR, Campbell GE, Aytoda P, Mathiesen AH \& Duffy DM 2019 Thrombospondin 1 (THBS1) promotes follicular angiogenesis, luteinization, and ovulation in primates. Frontiers in Endocrinology $\mathbf{1 0}$ 727. (https://doi.org/10.3389/fendo.2019.00727)

Benod C, Villagomez R, Filgueira CS, Hwang PK, Leonard PG, PoncetMontange G, Rajagopalan S, Fletterick RJ, Gustafsson JÅ \& Webb P 2014 The human orphan nuclear receptor tailless (TLX, NR2E1) is druggable. PLoS ONE 9 e99440. (https://doi.org/10.1371/journal. pone.0099440)

Benod C, Villagomez R \& Webb P 2016 TLX: an elusive receptor. Journal of Steroid Biochemistry and Molecular Biology 157 41-47. (https://doi. org/10.1016/j.jsbmb.2015.11.001)

Benoit G, Cooney A, Giguere V, Ingraham H, Lazar M, Muscat G, Perlmann T, Renaud JP, Schwabe J, Sladek F et al. 2006 International Union of Pharmacology. LXVI. Orphan nuclear receptors. Pharmacological Reviews 58 798-836. (https://doi.org/10.1124/pr.58.4.10)

Berisha B, Schams D, Kosmann M, Amselgruber W \& Einspanier R 2000 Expression and localisation of vascular endothelial growth factor and basic fibroblast growth factor during the final growth of bovine ovarian follicles. Journal of Endocrinology 167 371-382. (https://doi. org/10.1677/joe.0.1670371)

Berisha B, Schams D, Rodler D \& Pfaffl MW 2016a Angiogenesis in the ovary. The most important regulatory event for follicle and corpus luteum development and function in cow. An overview. Anatomia, Histologia, Embryologia 45 124-130. (https://doi.org/10.1111/ahe.12180)

Berisha B, Schams D, Rodler D, Sinowatz F \& Pfaffl MW 2016b Expression and localization of members of the thrombospondin family during final follicle maturation and corpus luteum formation and function in the bovine ovary. Journal of Reproduction and Development 62 501-510. (https://doi.org/10.1262/jrd.2016-056)

Bertacchi M, Parisot J \& Studer M 2019 The pleiotropic transcriptional regulator COUP-TFI plays multiple roles in neural development and disease. Brain Research 1705 75-94. (https://doi.org/10.1016/j. brainres.2018.04.024)

Bertolin K, Bellefleur AM, Zhang C \& Murphy BD 2010 Orphan nuclear receptor regulation of reproduction. Animal Reproduction 7 146-153.

Bertolin K, Gossen J, Schoonjans K \& Murphy BD 2014 The orphan nuclear receptor $\mathrm{Nr} 5 \mathrm{a} 2$ is essential for luteinization in the female mouse ovary. Endocrinology 155 1931-1943. (https://doi.org/10.1210/en.2013-1765) 
Bertolin K, Meinsohn MC, Suzuki J, Gossen J, Schoonjans K, Duggavathi R, Murphy BD 2017 Ovary-specific depletion of the nuclear receptor Nr5a2 compromises expansion of the cumulus oophorus but not fertilization by intracytoplasmic sperm injection. Biology of Reproduction 96 12311243. (https://doi.org/10.1093/biolre/iox045)

Besnard S, Silvestre JS, Duriez M, Bakouche J, Lemaigre-Dubreuil Y, Mariani J, Levy BI \& Tedgui A 2001 Increased ischemia-induced angiogenesis in the staggerer mouse, a mutant of the nuclear receptor ROR-alpha. Circulation Research 89 1209-1215. (https://doi. org/10.1161/hh2401.101755)

Bianco S, Bellefleur AM, Beaulieu É, Beauparlant CJ, Bertolin K, Droit A, Schoonjans K, Murphy BD \& Gévry N 2019 The ovulatory signal precipitates $\mathrm{LRH}-1$ transcriptional switching mediated by differential chromatin accessibility. Cell Report 27 2443.e4-2454.e4.

Bookout AL, Jeong Y, Downes M, Yu RT, Evans RM \& Mangelsdorf DJ 2006 Anatomical profiling of nuclear receptor expression reveals a hierarchical transcriptional network. Cell 126 789-799. (https://doi. org/10.1016/j.cell.2006.06.049)

Boonyaprakob U, Gadsby JE, Hedgpeth V, Routh P \& Almond GW 2003 Expression and localization of vascular endothelial growth factor and its receptors in pig corpora lutea during the oestrous cycle. Reproduction 126 393-405. (https://doi.org/10.1530/rep.0.1260393)

Brown HM, Robker RL \& Russell DL 2010 Development and hormonal regulation of the ovarian lymphatic vasculature. Endocrinology 151 5446-5455. (https://doi.org/10.1210/en.2010-0629)

Burgermeister E, Battaglin F, Eladly F, Wu W, Herweck F, Schulte N, Betge J, Härtel N, Kather JN, Weis CA et al. 2019 Aryl hydrocarbon receptor nuclear translocator-like (ARNTL/BMAL1) is associated with bevacizumab resistance in colorectal cancer via regulation of vascular endothelial growth factor A. EBiomedicine 45 139-154. (https://doi. org/10.1016/j.ebiom.2019.07.004)

Burris TP 2008 Nuclear hormone receptors for heme: REV-ERBalpha and REV-ERBbeta are ligand-regulated components of the mammalian clock. Molecular Endocrinology 22 1509-1520. (https://doi.org/10.1210/ me.2007-0519)

Carletti MZ \& Christenson LK 2009 Rapid effects of LH on gene expression in the mural granulosa cells of mouse periovulatory follicles. Reproduction 137 843-855. (https://doi.org/10.1530/REP-08-0457)

Cave MC, Clair HB, Hardesty JE, Falkner KC, Feng W, Clark BJ, Sidey J, Shi H, Aqel BA, McClain CJ et al. 2016 Nuclear receptors and nonalcoholic fatty liver disease. Biochimica et Biophysica Acta 1859 1083-1099. (https://doi.org/10.1016/j.bbagrm.2016.03.002)

Chanda D, Park JH \& Choi HS 2008 Molecular basis of endocrine regulation by orphan nuclear receptor small heterodimer partner. Endocrine Journal 55 253-268. (https://doi.org/10.1507/endocrj.k07e-103)

Chang C \& Kokontis J 1988 Identification of a new member of the steroid receptor super-family by cloning and sequence analysis. Biochemical and Biophysical Research Communications 155 971-977. (https://doi. org/10.1016/s0006-291x(88)80591-6)

Chang C, Kokontis J, Acakpo-Satchivi L, Liao S, Takeda H \& Chang Y 1989 Molecular cloning of new human TR2 receptors: a class of steroid receptor with multiple ligand-binding domains. Biochemical and Biophysical Research Communications 165 735-741. (https://doi. org/10.1016/s0006-291x(89)80028-2)

Chang C, Da Silva SL, Ideta R, Lee Y, Yeh S \& Burbach JP 1994 Human and rat TR4 orphan receptors specify a subclass of the steroid receptor superfamily. PNAS 91 6040-6044. (https://doi.org/10.1073/ pnas.91.13.6040)

Chen LM, Wang RS, Lee YF, Liu NC, Chang YJ, Wu CC, Xie S, Hung YC \& Chang C 2008 Subfertility with defective folliculogenesis in female mice lacking testicular orphan nuclear receptor 4. Molecular Endocrinology 22 858-867. (https://doi.org/10.1210/me.2007-0181)

Chen H, Chu G, Zhao L, Yamauchi N, Shigeyoshi Y, Hashimoto S \& Hattori MA 2012 Rev-erbo regulates circadian rhythms and StAR expression in rat granulosa cells as identified by the agonist GSK4112. Biochemical and Biophysical Research Communications 420 374-379. (https://doi.org/10.1016/j.bbrc.2012.02.164)

Chen H, Zhao L, Chu G, Kito G, Yamauchi N, Shigeyoshi Y, Hashimoto S \& Hattori MA 2013 FSH induces the development of circadian clockwork in rat granulosa cells via a Gap junction protein Cx43dependent pathway. American Journal of Physiology: Endocrinology and Metabolism $304 \quad$ E566-E575. (https://doi.org/10.1152/ ajpendo.00432.2012)

Chen C, Li Y, Hou S, Bourbon PM, Qin L, Zhao K, Ye T, Zhao D \& Zeng H 2020 Orphan nuclear receptor TR3/Nur77 biologics inhibit tumor growth by targeting angiogenesis and tumor cells. Microvascular Research $\mathbf{1 2 8}$ 103934. (https://doi.org/10.1016/j.mvr.2019.103934)

Cheng LE, Chan FK, Cado D \& Winoto A 1997 Functional redundancy of the Nur77 and Nor-1 orphan steroid receptors in T-cell apoptosis. EMBO Journal 16 1865-1875. (https://doi.org/10.1093/emboj/16.8.1865)

Chomez P, Neveu I, Mansén A, Kiesler E, Larsson L, Vennström B \& Arenas E 2000 Increased cell death and delayed development in the cerebellum of mice lacking the rev-erbA(alpha) orphan receptor. Development 127 1489-1498. (https://doi.org/10.1242/dev.127.7.1489)

Chung AC \& Cooney AJ 2001 Germ cell nuclear factor. International Journal of Biochemistry and Cell Biology 33 1141-1146. (https://doi. org/10.1016/s1357-2725(01)00081-4)

Coelho LA, Peres R, Amaral FG, Reiter RJ \& Cipolla-Neto J 2015 Daily differential expression of melatonin-related genes and clock genes in rat cumulus-oocyte complex: changes after pinealectomy. Journal of Pineal Research 58 490-499. (https://doi.org/10.1111/jpi.12234)

Dai A, Yan G, He Q, Jiang Y, Zhang Q, Fang T, Ding L, Sun J, Sun H \& Hu Y 2012 Orphan nuclear receptor Nur77 regulates androgen receptor gene expression in mouse ovary. PLOS ONE 7 e39950. (https://doi. org/10.1371/journal.pone.0039950)

Davis BJ, Lennard DE, Lee CA, Tiano HF, Morham SG, Wetsel WC \& Langenbach R 1999 Anovulation in cyclooxygenase-2-deficient mice is restored by prostaglandin E2 and interleukin-1 beta. Endocrinology $\mathbf{1 4 0}$ 2685-2695. (https://doi.org/10.1210/endo.140.6.6715)

Devesa J \& Caicedo D 2019 The role of growth hormone on ovarian functioning and ovarian angiogenesis. Frontiers in Endocrinology 10 450. (https://doi.org/10.3389/fendo.2019.00450)

DeYoung RA, Baker JC, Cado D \& Winoto A 2003 The orphan steroid receptor Nur77 family member Nor-1 is essential for early mouse embryogenesis. Journal of Biological Chemistry 278 47104-47109. (https://doi.org/10.1074/jbc.M307496200)

Divekar SD, Tiek DM, Fernandez A \& Riggins RB 2016 Estrogen-related receptor $\beta$ (ERR $\beta)$ - renaissance receptor or receptor renaissance? Nuclear Receptor Signaling 14 e002. (https://doi.org/10.1621/nrs.14002)

Duffy DM, Ko C, Jo M, Brannstrom M \& Curry TE 2019 Ovulation: parallels with inflammatory processes. Endocrine Reviews 40 369-416. (https://doi.org/10.1210/er.2018-00075)

Duggavathi R, Volle DH, Mataki C, Antal MC, Messaddeq N, Auwerx J, Murphy BD \& Schoonjans K 2008 Liver receptor homolog 1 is essential for ovulation. Genes and Development 22 1871-1876. (https://doi. org/10.1101/gad.472008)

Ehrlund A \& Treuter E 2012 Ligand-independent actions of the orphan receptors/co-repressors DAX-1 and SHP in metabolism, reproduction and disease. Journal of Steroid Biochemistry and Molecular Biology 130 169-179. (https://doi.org/10.1016/j.jsbmb.2011.04.007)

Erdős E \& Bálint BL 2019 COUP-TFII is a modulator of cell-type-specific genetic programs based on genomic localization maps. Journal of Biotechnology 301 11-17. (https://doi.org/10.1016/j.jbiotec.2019.05.305)

Fagiani E \& Christofori G 2013 Angiopoietins in angiogenesis. Cancer Letters 328 18-26. (https://doi.org/10.1016/j.canlet.2012.08.018)

Fan J, Lv Z, Yang G, Liao TT, Xu J, Wu F, Huang Q, Guo M, Hu G, Zhou M et al. 2018a Retinoic acid receptor-related orphan receptors: critical roles in tumorigenesis. Frontiers in Immunology 9 1187. (https://doi. org/10.3389/fimmu.2018.01187)

Fan W, He N, Lin CS, Wei Z, Hah N, Waizenegger W, He MX, Liddle C, Yu RT, Atkins AR et al. 2018b ERR $\gamma$ promotes angiogenesis, mitochondrial biogenesis, and oxidative remodeling in PGC1 $\alpha / \beta-$ deficient muscle. Cell Reports 22 2521-2529. (https://doi.org/10.1016/j. celrep.2018.02.047)

Fang Y, Zhang J, Li Y, Guo X, Li J, Zhong R \& Zhang X 2019 Melatonininduced demethylation of antioxidant genes increases antioxidant capacity through ROR $\alpha$ in cumulus cells of prepubertal lambs. Free Radical Biology and Medicine 131 173-183. (https://doi.org/10.1016/j. freeradbiomed.2018.11.027)

Farberov S, Basavaraja R \& Meidan R 2019 Thrombospondin-1 at the crossroads of corpus luteum fate decisions. Reproduction 157 R73-R83. (https://doi.org/10.1530/REP-18-0530) 
Ferraz-de-Souza B, Lin L \& Achermann JC 2011 Steroidogenic factor-1 (SF1, NR5A1) and human disease. Molecular and Cellular Endocrinology 336 198-205. (https://doi.org/10.1016/j.mce.2010.11.006)

Flaig R, Greschik H, Peluso-Iltis C \& Moras D 2005 Structural basis for the cell-specific activities of the NGFI-B and the Nurr1 ligand-binding domain. Journal of Biological Chemistry 280 19250-19258. (https://doi. org/10.1074/jbc.M413175200)

Fraser HM 2006 Regulation of the ovarian follicular vasculature. Reproductive Biology and Endocrinology 4 18. (https://doi. org/10.1186/1477-7827-4-18)

Fraser HM \& Wulff C 2001 Angiogenesis in the primate ovary. Reproduction, Fertility, and Development 13 557-566. (https://doi org/10.1071/rd01055)

Garattini E, Bolis M, Gianni M, Paroni G, Fratelli M \& Terao M 2016 Lipidsensors, enigmatic-orphan and orphan nuclear receptors as therapeutic targets in breast-cancer. Oncotarget 7 42661-42682. (https://doi. org/10.18632/oncotarget.7410)

Garside SA, Henkin J, Morris KD, Norvell SM, Thomas FH \& Fraser HM 2010 A thrombospondin-mimetic peptide, ABT-898, suppresses angiogenesis and promotes follicular atresia in pre- and earlyantral follicles in vivo. Endocrinology 151 5905-5915. (https://doi. org/10.1210/en.2010-0283)

Gillen J, Richardson D \& Moore K 2019 Angiopoietin-1 and angiopoietin-2 inhibitors: clinical development. Current Oncology Reports 2122. (https://doi.org/10.1007/s11912-019-0771-9)

Good DJ, Polverini PJ, Rastinejad F, Le Beau MM, Lemons RS, Frazier WA \& Bouck NP 1990 A tumor suppressor-dependent inhibitor of angiogenesis is immunologically and functionally indistinguishable from a fragment of thrombospondin. PNAS 87 6624-6628. (https://doi.org/10.1073/ pnas.87.17.6624)

Greenaway J, Gentry PA, Feige J, LaMarre J \& Petrik JJ 2005 Thrombospondin and vascular endothelial growth factor are cyclically expressed in an inverse pattern during bovine ovarian follicle development. Biology of Reproduction 72 1071-1078. (https://doi. org/10.1095/biolreprod.104.031120)

Greenaway J, Lawler J, Moorehead R, Bornstein P, Lamarre J \& Petrik J 2007 Thrombospondin-1 inhibits VEGF levels in the ovary directly by binding and internalization via the low density lipoprotein receptorrelated protein-1 (LRP-1). Journal of Cellular Physiology 210 807-818. (https://doi.org/10.1002/jcp.20904)

Greenwald GS 1989 Temporal and topographic changes in DNA synthesis after induced follicular atresia. Biology of Reproduction 41 175-181. (https://doi.org/10.1095/biolreprod41.1.175)

Guzmán A, Macías-Valencia R, Fierro-Fierro F, Gutiérrez CG \& RosalesTorres AM 2015 The corpora lutea proangiogenic state of VEGF system components is turned to antiangiogenic at the later phase of the oestrous cycle in cows. Animal 9 301-307. (https://doi.org/10.1017/ S1751731114002274)

Han P, Guerrero-Netro H, Estienne A, Cao B \& Price CA 2017 Regulation and action of early growth response 1 in bovine granulosa cells. Reproduction 154 547-557. (https://doi.org/10.1530/REP-17-0243)

Harper SJ \& Bates DO 2008 VEGF-A splicing: the key to anti-angiogenic therapeutics? Nature Reviews: Cancer 8 880-887. (https://doi. org/10.1038/nrc2505)

Hashemi Goradel N, Najafi M, Salehi E, Farhood B \& Mortezaee K 2019 Cyclooxygenase-2 in cancer: a review. Journal of Cellular Physiology 234 5683-5699. (https://doi.org/10.1002/jcp.27411)

Hayashi KG, Acosta TJ, Tetsuka M, Berisha B, Matsui M, Schams D, Ohtani M \& Miyamoto A 2003 Involvement of angiopoietin-tie system in bovine follicular development and atresia: messenger RNA expression in theca interna and effect on steroid secretion. Biology of Reproduction 69 2078-2084. (https://doi.org/10.1095/ biolreprod.103.017152)

Hayashi KG, Berisha B, Matsui M, Schams D \& Miyamoto A 2004 Expression of mRNA for the angiopoietin-tie system in granulosa cells during follicular development in cows. Journal of Reproduction and Development 50 477-480. (https://doi.org/10.1262/jrd.50.477)

Hazzard TM, Molskness TA, Chaffin CL \& Stouffer RL 1999 Vascular endothelial growth factor (VEGF) and angiopoietin regulation by gonadotrophin and steroids in macaque granulosa cells during the peri-ovulatory interval. Molecular Human Reproduction 5 1115-1121. (https://doi.org/10.1093/molehr/5.12.1115)
He QY, Ding LJ, Sun HX, Yu B, Dai AY, Zhang NY, Wang B, Yan GJ, Xu PZ \& Hu YL 2013 FSH modulates the expression of inhibin-alpha and the secretion of inhibins via orphan nuclear receptor NUR77 in ovarian granulosa cells. Molecular Reproduction and Development 80 734-743. (https://doi.org/10.1002/mrd.22206)

Hermann-Kleiter N \& Baier G 2014 Orphan nuclear receptor NR2F6 acts as an essential gatekeeper of Th17 CD4+ T cell effector functions. Cell Communication and Signaling 12 38. (https://doi.org/10.1186/1478811X-12-38)

Hernández-Morales J, Hernández-Coronado CG, Guzmán A, ZamoraGutiérrez D, Fierro F, Gutiérrez CG \& Rosales-Torres AM 2021 Hypoxia up-regulates VEGF ligand and downregulates VEGF soluble receptor mRNA expression in bovine granulosa cells in vitro. Theriogenology 165 76-83. (https://doi.org/10.1016/j.theriogenology.2021.02.006)

Herring JA, Elison WS \& Tessem JS 2019 Function of Nr4a orphan nuclear receptors in proliferation, apoptosis and fuel utilization across tissues. Cells 8 1373. (https://doi.org/10.3390/cells8111373)

Hizaki H, Segi E, Sugimoto Y, Hirose M, Saji T, Ushikubi F, Matsuoka T, Noda Y, Tanaka T, Yoshida N et al. 1999 Abortive expansion of the cumulus and impaired fertility in mice lacking the prostaglandin $\mathrm{E}$ receptor subtype EP(2). PNAS 96 10501-10506. (https://doi.org/10.1073/ pnas.96.18.10501)

Horard B \& Vanacker JM 2003 Estrogen receptor-related receptors: orphan receptors desperately seeking a ligand. Journal of Molecular Endocrinology 31 349-357. (https://doi.org/10.1677/jme.0.0310349)

Hu L, Sun Y, Luo J, He X, Ye M, Li G, Zhang Y, Bai J, Zhang D \& Chang C 2020 Targeting TR4 nuclear receptor with antagonist bexarotene increases docetaxel sensitivity to better suppress the metastatic castration-resistant prostate cancer progression. Oncogene 39 1891-1903. (https://doi. org/10.1038/s41388-019-1070-5)

Huang T, Sun L, Yuan X \& Qiu H 2017 Thrombospondin-1 is a multifaceted player in tumor progression. Oncotarget 8 84546-84558. (https://doi. org/10.18632/oncotarget.19165)

Hughes CHK \& Murphy BD 2021 Nuclear receptors: key regulators of somatic cell functions in the ovulatory process. Molecular Aspects of Medicine 78 100937. (https://doi.org/10.1016/j.mam.2020.100937)

Huss JM, Garbacz WG \& Xie W 2015 Constitutive activities of estrogenrelated receptors: transcriptional regulation of metabolism by the ERR pathways in health and disease. Biochimica et Biophysica Acta 1852 1912-1927. (https://doi.org/10.1016/j.bbadis.2015.06.016)

Isayama K, Zhao L, Chen H, Yamauchi N, Shigeyoshi Y, Hashimoto S \& Hattori MA 2015 Removal of Rev-erb $\alpha$ inhibition contributes to the prostaglandin $\mathrm{G} / \mathrm{H}$ synthase 2 expression in rat endometrial stromal cells. American Journal of Physiology: Endocrinology and Metabolism 308 E650-E661. (https://doi.org/10.1152/ajpendo.00533.2014)

Isidori AM, Venneri MA \& Fiore D 2016 Angiopoietin-1 and angiopoietin-2 in metabolic disorders: therapeutic strategies to restore the highs and lows of angiogenesis in diabetes. Journal of Endocrinological Investigation 39 1235-1246. (https://doi.org/10.1007/s40618-016-0502-0)

Ismail H, Mofarrahi M, Echavarria R, Harel S, Verdin E, Lim HW, Jin ZG, Sun J, Zeng H \& Hussain SN 2012 Angiopoietin-1 and vascular endothelial growth factor regulation of leukocyte adhesion to endothelial cells: role of nuclear receptor-77. Arteriosclerosis, Thrombosis, and Vascular Biology 32 1707-1716. (https://doi.org/10.1161/ATVBAHA.112.251546)

Jiang Z \& Price CA 2012 Differential actions of fibroblast growth factors on intracellular pathways and target gene expression in bovine ovarian granulosa cells. Reproduction 144 625-632. (https://doi.org/10.1530/ REP-12-0199)

Jiang JY, Macchiarelli G, Tsang BK \& Sato E 2003 Capillary angiogenesis and degeneration in bovine ovarian antral follicles. Reproduction 125 211-223. (https://doi.org/10.1530/rep.0.1250211)

Jiang ZL, Ripamonte P, Buratini J, Portela VM \& Price CA 2011 Fibroblast growth factor-2 regulation of sprouty and NR4A genes in bovine ovarian granulosa cells. Journal of Cellular Physiology 226 1820-1827. (https:// doi.org/10.1002/jcp.22509)

Jiang Z, Guerrero-Netro HM, Juengel JL \& Price CA 2013 Divergence of intracellular signaling pathways and early response genes of two closely related fibroblast growth factors, FGF8 and FGF18, in bovine ovarian granulosa cells. Molecular and Cellular Endocrinology 375 97-105. (https://doi.org/10.1016/j.mce.2013.05.017)

Jiang X, Wang J, Deng X, Xiong F, Zhang S, Gong Z, Li X, Cao K, Deng H, He $Y$ et al. 2020 The role of microenvironment in tumor angiogenesis. 
Journal of Experimental and Clinical Cancer Research 39 204. (https:// doi.org/10.1186/s13046-020-01709-5)

Kang Y, Zheng B, Shen B, Chen Y, Wang L, Wang J, Niu Y, Cui Y, Zhou J, Wang H et al. 2015 CRISPR/Cas9-mediated Dax1 knockout in the monkey recapitulates human AHC-HH. Human Molecular Genetics 24 7255-7264. (https://doi.org/10.1093/hmg/ddv425)

Karizbodagh MP, Rashidi B, Sahebkar A, Masoudifar A \& Mirzaei H 2017 Implantation window and angiogenesis. Journal of Cellular Biochemistry 118 4141-4151. (https://doi.org/10.1002/jcb.26088)

Kempisty B, Ziółkowska A, Ciesiółka S, Piotrowska H, Antosik P, Bukowska D, Brüssow KP, Nowicki M \& Zabel M 2015 Expression and cellular distribution of estrogen and progesterone receptors and the realtime proliferation of porcine cumulus cells. Zygote 23 836-845. (https:// doi.org/10.1017/S0967199414000495)

Kim SO, Harris SM \& Duffy DM 2014 Prostaglandin E2 (EP) receptors mediate PGE2-specific events in ovulation and luteinization within primate ovarian follicles. Endocrinology 155 1466-1475. (https://doi. org/10.1210/en.2013-2096)

Kim SO, Trau HA \& Duffy DM 2017 Vascular endothelial growth factors $\mathrm{C}$ and $\mathrm{D}$ may promote angiogenesis in the primate ovulatory follicle. Biology of Reproduction 96 389-400. (https://doi.org/10.1095/ biolreprod.116.144733)

Kizuka F, Tokuda N, Takagi K, Adachi Y, Lee L, Tamura I, Maekawa R, Taketani T, Tamura H, Suzuki T et al. 2012 Involvement of bone marrowderived vascular progenitor cells in neovascularization during formation of the corpus luteum in mice. Biology of Reproduction 87 55. (https:// doi.org/10.1095/biolreprod.112.099960)

Kojetin DJ \& Burris TP 2014 REV-ERB and ROR nuclear receptors as drug targets. Nature Reviews: Drug Discovery 13 197-216. (https://doi. org/10.1038/nrd4100)

Kokabu T, Mori T, Matsushima H, Yoriki K, Kataoka H, Tarumi Y \& Kitawaki J 2019 Antitumor effect of XCT790, an ERR $\alpha$ inverse agonist, on ER $\alpha$-negative endometrial cancer cells. Cellular Oncology 42 223-235. (https://doi.org/10.1007/s13402-019-00423-5)

Kurakula K, Koenis DS, van Tiel CM \& de Vries CJ 2014 NR4A nuclear receptors are orphans but not lonesome. Biochimica et Biophysica Acta 1843 2543-2555. (https://doi.org/10.1016/j.bbamcr.2014.06.010)

Lalli E \& Alonso J 2010 Targeting DAX-1 in embryonic stem cells and cancer. Expert Opinion on Therapeutic Targets 14 169-177. (https://doi. org/10.1517/14728220903531454)

Lalli E, Doghman M, Latre de Late P, El Wakil A \& Mus-Veteau I 2013 Beyond steroidogenesis: novel target genes for SF-1 discovered by genomics. Molecular and Cellular Endocrinology 371 154-159. (https:// doi.org/10.1016/j.mce.2012.11.005)

Land RH, Rayne AK, Vanderbeck AN, Barlowe TS, Manjunath S, Gross M, Eiger S, Klein PS, Cunningham NR, Huang J et al. 2015 The orphan nuclear receptor NR4A1 specifies a distinct subpopulation of quiescent myeloid-biased long-term HSCs. Stem Cells 33 278-288. (https://doi. org/10.1002/stem.1852)

Lawler PR \& Lawler J 2012 Molecular basis for the regulation of angiogenesis by thrombospondin-1 and -2. Cold Spring Harbor Perspectives in Medicine 2 a006627. (https://doi.org/10.1101/cshperspect.a006627)

Lazar MA 2016 Rev-erbs: integrating metabolism around the clock. In Research and Perspectives in Endocrine Interactions, pp. 63-70. Eds P Sassone-Corsi \& Y Christen. Cham: Springer. (https://doi. org/10.1007/978-3-319-27069-2_7)

Lee SL, Wesselschmidt RL, Linette GP, Kanagawa O, Russell JH \& Milbrandt J 1995 Unimpaired thymic and peripheral T cell death in mice lacking the nuclear receptor NGFI-B (Nur77). Science 269 532-535. (https://doi.org/10.1126/science.7624775)

Lee YF, Lee HJ \& Chang C 2002 Recent advances in the TR2 and TR4 orphan receptors of the nuclear receptor superfamily. Journal of Steroid Biochemistry and Molecular Biology 81 291-308. (https://doi. org/10.1016/s0960-0760(02)00118-8)

Li Y, Xia Y, Wang Y, Mao L, Gao Y, He Q, Huang M, Chen S \&Hu B 2013 Sonic hedgehog (Shh) regulates the expression of angiogenic growth factors in oxygen-glucose-deprived astrocytes by mediating the nuclear receptor NR2F2. Molecular Neurobiology 47 967-975. (https://doi. org/10.1007/s12035-013-8395-9)

Li M, Gallo D, Csizmadia E, Otterbein LE \& Wegiel B 2014 Carbon monoxide induces chromatin remodelling to facilitate endothelial cell migration. Thrombosis and Haemostasis 111 951-959. (https://doi. org/10.1160/TH13-09-0748)

Li Q, Wang Y, Zhang L, Chen L, Du Y, Ye T \& Shi X 2016 Naringenin exerts anti-angiogenic effects in human endothelial cells: involvement of $\mathrm{ERR} \alpha / V E G F / K D R$ signaling pathway. Fitoterapia 111 78-86. (https://doi. org/10.1016/j.fitote.2016.04.015)

Li XC, Yin XJ, Hong W, Liu J, Jin F, Wang BY, Wang YM \&Tian FJ 2019 The orphan nuclear receptor NUR77 promotes trophoblast invasion at early pregnancy through paracrine placental growth factor. Journal of Molecular Medicine 97 1359-1373. (https://doi.org/10.1007/s00109019-01819-4)

Likhite N, Yadav V, Milliman EJ, Sopariwala DH, Lorca S, Narayana NP, Sheth M, Reineke EL, Giguère V \& Narkar V 2019 Loss of estrogenrelated receptor alpha facilitates angiogenesis in endothelial cells. Molecular and Cellular Biology 39 15.e00411-15.e00418. (https://doi. org/10.1128/MCB.00411-18)

Lilis I, Giopanou I, Papadaki H \& Gyftopoulos K 2018 The expression of p-mTOR and COUP-TFII correlates with increased lymphangiogenesis and lymph node metastasis in prostate adenocarcinoma. Urologic Oncology $36 \quad 311 . e 27-311 . e 35 . \quad$ (https://doi.org/10.1016/j. urolonc.2018.02.007)

Lim H, Paria BC, Das SK, Dinchuk JE, Langenbach R, Trzaskos JM \& Dey SK 1997 Multiple female reproductive failures in cyclooxygenase 2-deficient mice. Cell 91 197-208. (https://doi.org/10.1016/s00928674(00)80402-x)

Lim M, Thompson JG \& Dunning KR 2021 Hypoxia and reproductive health: hypoxia and ovarian function: follicle development, ovulation, oocyte maturation. Reproduction 161 F33-F40. (https://doi.org/10.1530/ REP-20-0509)

Lin FJ, Qin J, Tang K, Tsai SY \& Tsai MJ 2011 Coup d'etat: an orphan takes control. Endocrine Reviews 32 404-421. (https://doi.org/10.1210/ er.2010-0021)

Lin Q, Aihara A, Chung W, Li Y, Chen X, Huang Z, Weng S, Carlson RI, Nadolny C, Wands JR et al. 2014a LRH1 promotes pancreatic cancer metastasis. Cancer Letters 350 15-24. (https://doi.org/10.1016/j. canlet.2014.04.017)

Lin Q, Aihara A, Chung W, Li Y, Huang Z, Chen X, Weng S, Carlson RI, Wands JR \& Dong X 2014b LRH1 as a driving factor in pancreatic cancer growth. Cancer Letters 345 85-90. (https://doi.org/10.1016/j. canlet.2013.11.014)

Lin SJ, Yang DR, Yang G, Lin CY, Chang HC, Li G \& Chang C 2017 TR2 and TR4 orphan nuclear receptors: an overview. Current Topics in Developmental Biology 125 357-373. (https://doi.org/10.1016/ bs.ctdb.2017.02.002)

Ling S, Ni RZ, Yuan Y, Dang YQ, Zhou QM, Liang S, Guo F, Feng W, Chen Y, Ikeda K et al. 2017 Natural compound bavachalcone promotes the differentiation of endothelial progenitor cells and neovascularization through the ROR $\alpha$-erythropoietin-AMPK axis. Oncotarget 8 86188-86205. (https://doi.org/10.18632/oncotarget.21036)

Liu D, Jia H, Holmes DI, Stannard A \& Zachary I 2003 Vascular endothelial growth factor-regulated gene expression in endothelial cells: KDRmediated induction of Egr3 and the related nuclear receptors Nur77, Nurr1, and Nor1. Arteriosclerosis, Thrombosis, and Vascular Biology 23 2002-2009.

Liu S, Lin SJ, Li G, Kim E, Chen YT, Yang DR, Tan MH, Yong EL \& Chang C 2014 Differential roles of PPAR $\gamma$ vs TR4 in prostate cancer and metabolic diseases. Endocrine-Related Cancer 21 R279-R300. (https://doi. org/10.1530/ERC-13-0529)

Lu H 2016 Crosstalk of HNF4 $\alpha$ with extracellular and intracellular signaling pathways in the regulation of hepatic metabolism of drugs and lipids. Acta Pharmaceutica Sinica: B 6 393-408. (https://doi.org/10.1016/j. apsb.2016.07.003)

Luo J, Sladek R, Carrier J, Bader JA, Richard D \& Giguère V 2003 Reduced fat mass in mice lacking orphan nuclear receptor estrogen-related receptor alpha. Molecular and Cellular Biology 23 7947-7956. (https:// doi.org/10.1128/MCB.23.22.7947-7956.2003)

Luo H, Rankin GO, Liu L, Daddysman MK, Jiang BH \& Chen YC 2009 Kaempferol inhibits angiogenesis and VEGF expression through both HIF dependent and independent pathways in human ovarian cancer cells. Nutrition and Cancer 61 554-563. (https://doi. org/10.1080/01635580802666281) 
Mangelsdorf DJ, Thummel C, Beato M, Herrlich P, Schütz G, Umesono K, Blumberg B, Kastner P, Mark M, Chambon P et al. 1995 The nuclear receptor superfamily: the second decade. Cell 83 835-839. (https://doi. org/10.1016/0092-8674(95)90199-x)

Martelli A, Palmerini MG, Russo V, Rinaldi C, Bernabò N, Di Giacinto $O$, Berardinelli P, Nottola SA, Macchiarelli G \& Barboni B 2009 Blood vessel remodeling in pig ovarian follicles during the periovulatory period: an immunohistochemistry and SEM-corrosion casting study. Reproductive Biology and Endocrinology 7 72. (https://doi.org/10.1186/1477-7827-7-72)

Martorell L, Gentile M, Rius J, Rodríguez C, Crespo J, Badimon L \& Martínez-González J 2009 The hypoxia-inducible factor 1/NOR1 axis regulates the survival response of endothelial cells to hypoxia. Molecular and Cellular Biology 29 5828-5842. (https://doi.org/10.1128/ MCB.00945-09)

Maruyama K, Tsukada T, Ohkura N, Bandoh S, Hosono T \& Yamaguchi K 1998 The NGFI-B subfamily of the nuclear receptor superfamily (review). International Journal of Oncology 12 1237-1243. (https://doi. org/10.3892/ijo.12.6.1237)

Matsushima H, Mori T, Ito F, Yamamoto T, Akiyama M, Kokabu T, Yoriki K, Umemura S, Akashi K \& Kitawaki J 2016 Anti-tumor effect of estrogenrelated receptor alpha knockdown on uterine endometrial cancer. Oncotarget 7 34131-34148. (https://doi.org/10.18632/oncotarget.9151)

Mattioli M, Barboni B, Turriani M, Galeati G, Zannoni A, Castellani G, Berardinelli P \& Scapolo PA 2001 Follicle activation involves vascular endothelial growth factor production and increased blood vessel extension. Biology of Reproduction 65 1014-1019. (https://doi. org/10.1095/biolreprod65.4.1014)

McMorrow JP, Crean D, Gogarty M, Smyth A, Connolly M, Cummins E, Veale D, Fearon U, Tak PP, Fitzgerald O et al. 2013 Tumor necrosis factor inhibition modulates thrombospondin-1 expression in human inflammatory joint disease through altered NR4A2 activity. American Journal of Pathology 183 1243-1257. (https://doi.org/10.1016/j. ajpath.2013.06.029)

McNatty KP 1981 Hormonal correlates of follicular development in the human ovary. Australian Journal of Biological Sciences 34 249-268. (https://doi.org/10.1071/bi9810249)

Medzikovic L, de Vries CJM \& de Waard V 2019 NR4A nuclear receptors in cardiac remodeling and neurohormonal regulation. Trends in Cardiovascular Medicine 29 429-437. (https://doi.org/10.1016/j. tcm.2018.11.015

Meinsohn MC, Smith OE, Bertolin K \& Murphy BD 2019 The orphan nuclear receptors steroidogenic factor-1 and liver receptor homolog-1: structure, regulation, and essential roles in mammalian reproduction. Physiological Reviews 99 1249-1279. (https://doi.org/10.1152/ physrev.00019.2018)

Melincovici CS, Boşca AB, Şuşman S, Mărginean $M$, Mihu C, Istrate $M$, Moldovan IM, Roman AL \& Mihu CM 2018 Vascular endothelial growth factor (VEGF) - key factor in normal and pathological angiogenesis. Romanian Journal of Morphology and Embryology 59 455-467.

Miao L, Shi J, Wang CY, Zhu Y, Du X, Jiao H, Mo Z, Klocker H, Lee C \& Zhang J 2010 Estrogen receptor-related receptor alpha mediates up-regulation of aromatase expression by prostaglandin E2 in prostate stromal cells. Molecular Endocrinology 24 1175-1186. (https://doi. org/10.1210/me.2009-0470)

Misawa A \& Inoue S 2015 Estrogen-related receptors in breast cancer and prostate cancer. Frontiers in Endocrinology 6 83. (https://doi. org/10.3389/fendo.2015.00083)

Mitsunaga K, Araki K, Mizusaki H, Morohashi K, Haruna K, Nakagata N, Giguère V, Yamamura K \& Abe K 2004 Loss of PGC-specific expression of the orphan nuclear receptor ERR-beta results in reduction of germ cell number in mouse embryos. Mechanisms of Development 121 237-246. (https://doi.org/10.1016/j.mod.2004.01.006)

Miyabayashi K, Shimizu T, Kawauchi C, Sasada H \& Sato E 2005 Changes of mRNA expression of vascular endothelial growth factor, angiopoietins and their receptors during the periovulatory period in eCG/hCGtreated immature female rats. Journal of Experimental Zoology: Part A, Comparative Experimental Biology 303 590-597. (https://doi. org/10.1002/jez.a.188

Młynarczuk J \& Rekawiecki R 2010 The role of the orphan receptor SF-1 in the development and function of the ovary. Reproductive Biology $\mathbf{1 0}$ 177-193. (https://doi.org/10.1016/S1642-431X(12)60039-4)
Mohan HM, Aherne CM, Rogers AC, Baird AW, Winter DC \& Murphy EP 2012 Molecular pathways: the role of NR4A orphan nuclear receptors in cancer. Clinical Cancer Research 18 3223-3228. (https://doi. org/10.1158/1078-0432.CCR-11-2953)

Moldovan SM, Nervina JM, Tetradis S \& Camargo PM 2009 Regulation of Nur77 gene expression by prostanoids in cementoblastic cells. Archives of Oral Biology $\mathbf{5 4}$ 412-419. (https://doi.org/10.1016/j. archoralbio.2009.01.013)

Murayama C, Miyazaki H, Miyamoto A \& Shimizu T 2008 Involvement of Ad4BP/SF-1, DAX-1, and COUP-TFIl transcription factor on steroid production and luteinization in ovarian theca cells. Molecular and Cellular Biochemistry 314 51-58. (https://doi.org/10.1007/s11010-0089764-y)

Nakamura Y, Vargas Morris C, Sasano H \& Rainey WE 2009 DAX-1A (NROB1A) expression levels are extremely low compared to DAX1 (NROB1) in human steroidogenic tissues. Hormone and Metabolic Research 41 30-34. (https://doi.org/10.1055/s-0028-1087174)

Nejabat M, Charbgoo F \& Ramezani M 2017 Graphene as multifunctional delivery platform in cancer therapy. Journal of Biomedical Materials Research: Part A 105 2355-2367. (https://doi.org/10.1002/ jbm.a.36080)

Ning Z, Du X, Zhang J, Yang K, Miao L, Zhu Y, Yuan H, Wang L, Klocker H \& Shi J 2014 PGE2 modulates the transcriptional activity of ERRa in prostate stromal cells. Endocrine 47 901-912. (https://doi.org/10.1007/ s12020-014-0261-7)

Novac N \& Heinzel T 2004 Nuclear receptors: overview and classification. Current Drug Targets: Inflammation and Allergy 3 335-346. (https://doi. org/10.2174/1568010042634541)

Nowak DG, Woolard J, Amin EM, Konopatskaya O, Saleem MA, Churchill AJ, Ladomery MR, Harper SJ \& Bates DO 2008 Expression of pro- and anti-angiogenic isoforms of VEGF is differentially regulated by splicing and growth factors. Journal of Cell Science 121 3487-3495. (https://doi.org/10.1242/jcs.016410)

Orekhova AS \& Rubtsov PM 2015 DAX1-unusual member of nuclear receptors superfamily with diverse functions. Molekuliarnaia Biologiia 49 75-88. (https://doi.org/10.1134/S0026893315010124)

Ortega-Serrano PV, Guzmán A, Hernández-Coronado CG, CastilloJuárez H \& Rosales-Torres AM 2016 Reduction in the mRNA expression of sVEGFR1 and sVEGFR2 is associated with the selection of dominant follicle in cows. Reproduction in Domestic Animals 51 985-991. (https:// doi.org/10.1111/rda.12777)

Osz K, Ross M \& Petrik J 2014 The thrombospondin-1 receptor CD36 is an important mediator of ovarian angiogenesis and folliculogenesis. Reproductive Biology and Endocrinology 12 21. (https://doi. org/10.1186/1477-7827-12-21)

Owen LA, Uehara H, Cahoon J, Huang W, Simonis J \& Ambati BK 2012 Morpholino-mediated increase in soluble Flt-1 expression results in decreased ocular and tumo neovascularization. PLOS ONE 733576. (https://doi.org/10.1371/journal.pone.0033576)

Pawlak M, Lefebvre P \& Staels B 2015 Molecular mechanism of PPAR $\alpha$ action and its impact on lipid metabolism, inflammation and fibrosis in non-alcoholic fatty liver disease. Journal of Hepatology 62 720-733. (https://doi.org/10.1016/j.jhep.2014.10.039)

Peng J, Zhao S, Li Y, Niu G, Chen C, Ye T, Zhao D \& Zeng H 2019 DLL4 and Jagged1 are angiogenic targets of orphan nuclear receptor TR3/ Nur77. Microvascular Research 124 67-75. (https://doi.org/10.1016/j. mvr.2019.03.006)

Pereira FA, Qiu Y, Zhou G, Tsai MJ \& Tsai SY 1999 The orphan nuclear receptor COUP-TFII is required for angiogenesis and heart development. Genes and Development 13 1037-1049. (https://doi.org/10.1101/ gad.13.8.1037)

Petit FG, Jamin SP, Kurihara I, Behringer RR, DeMayo FJ, Tsai MJ \& Tsai SY 2007 Deletion of the orphan nuclear receptor COUP-TFII in uterus leads to placental deficiency. PNAS 104 6293-6298. (https://doi.org/10.1073/ pnas.0702039104)

Plendl J 2000 Angiogenesis and vascular regression in the ovary. Anatomia, Histologia, Embryologia 29 257-266. (https://doi.org/10.1046/j.14390264.2000.00265.x)

Polvani S, Tarocchi M, Tempesti S, Mello T, Ceni E, Buccoliero F, D'Amico M, Boddi V, Farsi M, Nesi S et al. 2014 COUP-TFII in pancreatic adenocarcinoma: clinical implication for patient survival 
and tumor progression. International Journal of Cancer 134 1648-1658. (https://doi.org/10.1002/ijc.28502)

Ponnio T, Burton Q, Pereira FA, Wu DK \& Conneely OM 2002 The nuclear receptor Nor-1 is essential for proliferation of the semicircular canals of the mouse inner ear. Molecular and Cellular Biology 22 935-945. (https://doi.org/10.1128/MCB.22.3.935-945.2002)

Porter BA, Ortiz MA, Bratslavsky G \& Kotula L 2019 Structure and function of the nuclear receptor superfamily and current targeted therapies of prostate cancer. Cancers 11 1852. (https://doi.org/10.3390/cancers11121852)

Preitner N, Damiola F, Lopez-Molina L, Zakany J, Duboule D, Albrecht U \& Schibler U 2002 The orphan nuclear receptor REV-ERBalpha controls circadian transcription within the positive limb of the mammalian circadian oscillator. Cell 110 251-260. (https://doi.org/10.1016/s00928674(02)00825-5)

Przygrodzka E, Kaczmarek MM, Kaczynski P \& Ziecik AJ 2016 Steroid hormones, prostanoids, and angiogenic systems during rescue of the corpus luteum in pigs. Reproduction 151 135-147. (https://doi. org/10.1530/REP-15-0332)

Qin J, Chen X, Yu-Lee LY, Tsai MJ \& Tsai SY 2010a Nuclear receptor COUP-TFII controls pancreatic islet tumor angiogenesis by regulating vascular endothelial growth factor/vascular endothelial growth factor receptor-2 signaling. Cancer Research 70 8812-8821. (https://doi. org/10.1158/0008-5472.CAN-10-0551)

Qin J, Chen X, Xie X, Tsai MJ \& Tsai SY $2010 b$ COUP-TFII regulates tumor growth and metastasis by modulating tumor angiogenesis. PNAS $\mathbf{1 0 7}$ 3687-3692. (https://doi.org/10.1073/pnas.0914619107)

Qiu Y, Seager M, Osman A, Castle-Miller J, Bevan H, Tortonese DJ, Murphy D, Harper SJ, Fraser HM, Donaldson LF et al. 2012 Ovarian VEGF(165)b expression regulates follicular development, corpus luteum function and fertility. Reproduction 143 501-511. (https://doi. org/10.1530/REP-11-0091)

Qin L, Zhao D, Xu J, Ren X, Terwilliger EF, Parangi S, Lawler J, Dvorak HF \& Zeng H 2013 The vascular permeabilizing factors histamine and serotonin induce angiogenesis through TR3/Nur77 and subsequently truncate it through thrombospondin-1. Blood 121 2154-2164. (https:// doi.org/10.1182/blood-2012-07-443903)

Raccurt M, Smallwood S, Mertani HC, Devost D, Abbaci K, Boutin JM \& Morel G 2005 Cloning, expression and regulation of chicken ovalbumin upstream promoter transcription factors (COUP-TFII and EAR-2) in the rat anterior pituitary gland. Neuroendocrinology 82 233-244. (https:// doi.org/10.1159/000092752)

Ravel C, Hyon C, Siffroi JP \& Christin-Maitre S 2014 Are human male patients with DAX1/NR0B1 mutations infertile? Annales d'Endocrinologie 75 126-127. (https://doi.org/10.1016/j.ando.2014.03.003)

Reynolds LP \& Redmer DA 1998 Expression of the angiogenic factors, basic fibroblast growth factor (bFGF) and vascular endothelial growth factor (VEGF), in the ovary. Invited review. Journal of Animal Science $\mathbf{7 6}$ 1671-1681. (https://doi.org/10.2527/1998.7661671x)

Riggins RB, Mazzotta MM, Maniya OZ \& Clarke R 2010 Orphan nuclear receptors in breast cancer pathogenesis and therapeutic response. Endocrine Relatated Cancer 17 213-244.

Rius J, Martínez-González J, Crespo J \& Badimon L 2006 NOR-1 is involved in VEGF-induced endothelial cell growth. Atherosclerosis $\mathbf{1 8 4}$ 276-282. (https://doi.org/10.1016/j.atherosclerosis.2005.04.008)

Rizov M, Andreeva P \& Dimova I 2017 Molecular regulation and role of angiogenesis in reproduction. Taiwanese Journal of Obstetrics and Gynecology 56 127-132. (https://doi.org/10.1016/j.tjog.2016.06.019)

Robinson RS, Woad KJ, Hammond AJ, Laird M, Hunter MG \& Mann GE 2009 Angiogenesis and vascular function in the ovary. Reproduction 138 869-881. (https://doi.org/10.1530/REP-09-0283)

Robinson-Rechavi M, Escriva Garcia H \& Laudet V 2003 The nuclear receptor superfamily. Journal of Cell Science 116 585-586. (https://doi. org/10.1242/jcs.00247)

Rosales-Torres AM \& Guzmán-Sánchez A 2012 Importancia del Factor de Crecimiento del Endotelio Vascular (VEGF) y de sus receptores en el ciclo ovárico. Revisión. Revista Mexicana de Ciencias Pecuarias 3 89-111.

Ryffel GU 2001 Mutations in the human genes encoding the transcription factors of the hepatocyte nuclear factor (HNF)1 and HNF4 families: functional and pathological consequences. Journal of Molecular Endocrinology 27 11-29. (https://doi.org/10.1677/jme.0.0270011)

Salmon NA, Handyside AH \& Joyce IM 2005 Expression of Sox8, Sf1, Gata4, Wt1, Dax1, and Fog2 in the mouse ovarian follicle: implications for the regulation of Amh expression. Molecular Reproduction and Development $70271-278$.

Sasaki S, Urabe M, Maeda T, Suzuki J, Irie R, Suzuki M, Tomaru Y, Sakaguchi M, Gonzalez FJ \& Inoue Y 2018 Induction of hepatic metabolic functions by a novel variant of hepatocyte nuclear factor $4 \gamma$. Molecular and Cellular Biology 38 28.e00213-28.e00218. (https://doi. org/10.1128/MCB.00213-18)

Sato Y, Suzuki T, Hidaka K, Sato H, Ito K, Ito S \& Sasano H 2003 Immunolocalization of nuclear transcription factors, DAX-1 and COUPTF II, in the normal human ovary: correlation with adrenal 4 binding protein/steroidogenic factor-1 immunolocalization during the menstrual cycle. Journal of Clinical Endocrinology and Metabolism 88 3415-3420. (https://doi.org/10.1210/jc.2002-021723)

Saxena D, Escamilla-Hernandez R, Little-Ihrig L \& Zeleznik AJ 2007 Liver receptor homolog-1 and steroidogenic factor-1 have similar actions on rat granulosa cell steroidogenesis. Endocrinology 148 726-734. (https:// doi.org/10.1210/en.2006-0108)

Sayed RKA, Mokhtar DM, Fernández-Ortiz M, Escames G \& AcuñaCastroviejo D 2019 Retinoid-related orphan nuclear receptor alpha $(\operatorname{ROR} \alpha)$-deficient mice display morphological testicular defects. Laboratory Investigation 99 1835-1849. (https://doi.org/10.1038/ s41374-019-0299-5)

Schmitz V, Vilanueva H, Raskopf E, Hilbert T, Barajas M, Dzienisowicz C, Gorschlüter M, Strehl J, Rabe C, Sauerbruch T et al. 2006 Increased VEGF levels induced by anti-VEGF treatment are independent of tumor burden in colorectal carcinomas in mice. Gene Therapy 13 1198-1205. (https://doi.org/10.1038/sj.gt.3302772)

Schorderet DF \& Escher P 2009 NR2E3 mutations in enhanced S-cone sensitivity syndrome (ESCS), Goldmann-Favre syndrome (GFS), clumped pigmentary retinal degeneration (CPRD), and retinitis pigmentosa (RP). Human Mutation 30 1475-1485. (https://doi.org/10.1002/ humu.21096)

Segers I, Adriaenssens T, Wathlet S \& Smitz J 2012 Gene expression differences induced by equimolar low doses of LH or hCG in combination with $\mathrm{FSH}$ in cultured mouse antral follicles. Journal of Endocrinology 215 269-280. (https://doi.org/10.1530/JOE-12-0150)

Shibuya M 2015 VEGF-VEGFR system as a target for suppressing inflammation and other diseases. Endocrine, Metabolic and Immune Disorders Drug Targets 15 135-144. (https://doi.org/10.2174/1871530 315666150316121956)

Shimizu T, Jiang JY, lijima K, Miyabayashi K, Ogawa Y, Sasada H \& Sato E 2003 Induction of follicular development by direct single injection of vascular endothelial growth factor gene fragments into the ovary of miniature gilts. Biology of Reproduction 69 1388-1393. (https://doi. org/10.1095/biolreprod.103.016311)

Shimizu T, Berisha B, Schams D \& Miyamoto A 2007 Expression of angiopoietin (ANPT)-1, ANPT-2 and their receptors in dominant follicles during periovulatory period in $\mathrm{GnRH}$-treated cow. Reproduction in Domestic Animals 42 221-224. (https://doi.org/10.1111/j.14390531.2006.00748.x)

Shimizu T, Sudo N, Yamashita H, Murayama C, Miyazaki H \& Miyamoto A 2009 Histone H3 acetylation of StAR and decrease in DAX-1 is involved in the luteinization of bovine granulosa cells during in vitro culture. Molecular and Cellular Biochemistry 328 41-47. (https://doi. org/10.1007/s11010-009-0072-y)

Shin D, Kim IS, Lee JM, Shin SY, Lee JH, Baek SH \& Cho KH 2014 The hidden switches underlying ROR $\alpha$-mediated circuits that critically regulate uncontrolled cell proliferation. Journal of Molecular Cell Biology 6 338-348. (https://doi.org/10.1093/jmcb/mju023)

Smalling RL, Delker DA, Zhang Y, Nieto N, McGuiness MS, Liu S, Friedman SL, Hagedorn CH \& Wang L 2013 Genome-wide transcriptome analysis identifies novel gene signatures implicated in human chronic liver disease. American Journal of Physiology: Gastrointestinal and Liver Physiology 305 G364-G374. (https://doi. org/10.1152/ajpgi.00077.2013)

Sobhan PK \& Funa K 2017 TLX-Its Emerging role for neurogenesis in health and disease. Molecular Neurobiology 54 272-280. (https://doi. org/10.1007/s12035-015-9608-1)

Solt LA, Kumar N, Nuhant P, Wang Y, Lauer JL, Liu J, Istrate MA, Kamenecka TM, Roush WR, Vidović D et al. 2011 Suppression of TH17 differentiation and autoimmunity by a synthetic ROR ligand. Nature 472 491-494. (https://doi.org/10.1038/nature10075) 
Sonoda J, Pei L \& Evans RM 2008 Nuclear receptors: decoding metabolic disease. FEBS Letters 582 2-9. (https://doi.org/10.1016/j. febslet.2007.11.016)

Stein RA \& McDonnell DP 2006 Estrogen-related receptor $\alpha$ as a therapeutic target in cancer. Endocrine-Related Cancer 13 (Supplement 1) S25-S32. (available at: https://erc.bioscientifica.com/view/journals/ erc/13/Supplement_1/0130025) (https://doi.org/10.1677/erc.1.01292)

Stevens M \& Oltean S 2019 Modulation of receptor tyrosine kinase activity through alternative splicing of ligands and receptors in the VEGF-A/ VEGFR axis. Cells 8 288. (https://doi.org/10.3390/cells8040288)

Sun Y, Liu CH, SanGiovanni JP, Evans LP, Tian KT, Zhang B, Stahl A, Pu WT, Kamenecka TM, Solt LA et al. 2015 Nuclear receptor RORalpha regulates pathologic retinal angiogenesis by modulating SOCS3dependent inflammation. PNAS 112 10401-10406. (https://doi. org/10.1073/pnas.1504387112)

Sun Y, Liu CH, Wang Z, Meng SS, Burnim SB, SanGiovanni JP, Kamenecka TM, Solt LA \& Chen J 2017 ROR $\alpha$ modulates semaphorin 3E transcription and neurovascular interaction in pathological retinal angiogenesis. FASEB Journal 31 4492-4502. (https://doi.org/10.1096/fj.201700172R)

Suntharalingham JP, Buonocore F, Duncan AJ \& Achermann JC 2015 DAX1 (NR0B1) and steroidogenic factor-1 (SF-1, NR5A1) in human disease. Best Practice and Research: Clinical Endocrinology and Metabolism 29 607-619. (https://doi.org/10.1016/j.beem.2015.07.004)

Suyama K, Silagi ES, Choi H, Sakabe K, Mochida J, Shapiro IM \& Risbud MV 2016 Circadian factors BMAL1 and ROR $\alpha$ control HIF$1 \alpha$ transcriptional activity in nucleus pulposus cells: implications in maintenance of intervertebral disc health. Oncotarget 7 23056-23071. (https://doi.org/10.18632/oncotarget.8521)

Szentirmai O, Baker CH, Bullain SS, Lin N, Takahashi M, Folkman J, Mulligan RC \& Carter BS 2008 Successful inhibition of intracranial human glioblastoma multiforme xenograft growth via systemic adenoviral delivery of soluble endostatin and soluble vascular endothelial growth factor receptor-2: laboratory investigation. Journal of Neurosurgery 108 979-988. (https://doi.org/10.3171/JNS/2008/108/5/0979)

Tajima K, Dantes A, Yao Z, Sorokina K, Kotsuji F, Seger R \& Amsterdam A 2003 Down-regulation of steroidogenic response to gonadotropins in human and rat preovulatory granulosa cells involves mitogen-activated protein kinase activation and modulation of DAX-1 and steroidogenic factor-1. Journal of Clinical Endocrinology and Metabolism 88 2288-2299. (https://doi.org/10.1210/jc.2002-020913)

Takae K, Nakata M, Watanabe T, Sasada H, Fujii H \& Tomioka I 2019 Evidence for the involvement of FXR signaling in ovarian granulosa cell function. Journal of Reproduction and Development 65 47-55. (https:// doi.org/10.1262/jrd.2018-054)

Takamoto N, Kurihara I, Lee K, Demayo FJ, Tsai MJ \& Tsai SY 2005 Haploinsufficiency of chicken ovalbumin upstream promoter transcription factor II in female reproduction. Molecular Endocrinology 19 2299-2308. (https://doi.org/10.1210/me.2005-0019)

Talia DM, Deliyanti D, Agrotis A \& Wilkinson-Berka JL 2016 Inhibition of the nuclear receptor ROR $\gamma$ and interleukin-17A suppresses neovascular retinopathy: involvement of immunocompetent microglia. Arteriosclerosis, Thrombosis, and Vascular Biology 36 1186-1196. (https://doi.org/10.1161/ATVBAHA.115.307080)

Tamanini C \& De Ambrogi M 2004 Angiogenesis in developing follicle and corpus luteum. Reproduction in Domestic Animals 39 206-216. (https:// doi.org/10.1111/j.1439-0531.2004.00505.x)

Tamura R, Fujioka M, Morimoto Y, Ohara K, Kosugi K, Oishi Y, Sato M, Ueda R, Fujiwara H, Hikichi T et al. 2019 A VEGF receptor vaccine demonstrates preliminary efficacy in neurofibromatosis type 2. Nature Communications 10 5758. (https://doi.org/10.1038/s41467-019-13640-1)

Tan MH, Zhou XE, Soon FF, Li X, Li J, Yong EL, Melcher K \& Xu HE 2013 The crystal structure of the orphan nuclear receptor NR2E3/PNR ligand binding domain reveals a dimeric auto-repressed conformation. PLoS ONE 8 e74359. (https://doi.org/10.1371/journal.pone.0074359)

Tang K, Tsai SY \& Tsai MJ 2015 COUP-TFs and eye development. Biochimica et Biophysica Acta 1849 201-209. (https://doi.org/10.1016/j. bbagrm.2014.05.022)

Taraviras S, Mantamadiotis T, Dong-Si T, Mincheva A, Lichter P, Drewes T, Ryffel GU, Monaghan AP \& Schütz G 2000 Primary structure, chromosomal mapping, expression and transcriptional activity of murine hepatocyte nuclear factor $4 \gamma$. Biochimica et biophysica acta 1490 21-32. (https://doi.org/10.1016/s0167-4781(99)00232-8)
Taylor PD, Wilson H, Hillier SG, Wiegand SJ \& Fraser HM 2007 Effects of inhibition of vascular endothelial growth factor at time of selection on follicular angiogenesis, expansion, development and atresia in the marmoset. Molecular Human Reproduction 13 729-736. (https://doi. org/10.1093/molehr/gam056)

Thomas FH, Wilson H, Silvestri A \& Fraser HM 2008 Thrombospondin-1 expression is increased during follicular atresia in the primate ovary. Endocrinology 149 185-192. (https://doi.org/10.1210/en.2007-0835)

Tiwari D \& Gupta P 2021 Nuclear receptors in asthma: empowering classical molecules against a contemporary ailment. Frontiers in Immunology 26594433.

Toi M, Bando H, Ogawa T, Muta M, Hornig C \& Weich HA 2002 Significance of vascular endothelial growth factor (VEGF)/soluble VEGF receptor-1 relationship in breast cancer. International Journal of Cancer 98 14-18. (https://doi.org/10.1002/ijc.10121)

Trau HA, Davis JS \& Duffy DM 2015 Angiogenesis in the primate ovulatory follicle is stimulated by luteinizing hormone via prostaglandin E2. Biology of Reproduction 92 15. (https://doi.org/10.1095/ biolreprod.114.123711)

Trau HA, Brännström M, Curry Jr TE \& Duffy DM 2016 Prostaglandin E2 and vascular endothelial growth factor A mediate angiogenesis of human ovarian follicular endothelial cells. Human Reproduction 31 436-444. (https://doi.org/10.1093/humrep/dev320)

Trenti A, Tedesco S, Boscaro C, Trevisi L, Bolego C \& Cignarella A 2018 Estrogen, angiogenesis, immunity and cell metabolism: solving the puzzle. International Journal of Molecular Sciences 19 859. (https://doi. org/10.3390/ijms19030859)

Vrachnis N, Kalampokas E, Sifakis S, Vitoratos N, Kalampokas T, Botsis D \& Iliodromiti Z 2013 Placental growth factor (PIGF): a key to optimizing fetal growth. Journal of Maternal-Fetal and Neonatal Medicine 26 995-1002. (https://doi.org/10.3109/14767058.2013.766694)

Waltenberger J, Claesson-Welsh L, Siegbahn A, Shibuya M \& Heldin CH 1994 Different signal transduction properties of KDR and Flt1, two receptors for vascular endothelial growth factor. Journal of Biological Chemistry $26926988-26995$.

Wang Q \& Cooney AJ 2013 Revisiting the role of GCNF in embryonic development. Seminars in Cell and Developmental Biology 24 679-686. (https://doi.org/10.1016/j.semcdb.2013.08.003)

Wang T \& Xiong JQ 2016 The orphan nuclear receptor TLX/NR2E1 in neural stem cells and diseases. Neuroscience Bulletin 32 108-114. (https://doi.org/10.1007/s12264-015-0004-7)

Wang Z, Benoit G, Liu J, Prasad S, Aarnisalo P, Liu X, Xu H, Walker NP \& Perlmann T 2003 Structure and function of Nurr1 identifies a class of ligand-independent nuclear receptors. Nature 423 555-560. (https://doi. org/10.1038/nature01645)

Wang XX, Wang XX, Jia XF, Guo T, Xian TZ, Liu L, Xu ZJ, Guo Y, Deng X, Zhang LN et al. 2019 Novel role of SF1 in alleviating thyroid-associated ophthalmopathy through the AMPK/mTOR signaling pathway. Gene 691 132-140. (https://doi.org/10.1016/j.gene.2018.11.097)

Wang S, Li F, Lin Y \& Wu B 2020 Targeting REV-ERB $\alpha$ for therapeutic purposes: promises and challenges. Theranostics 10 4168-4182. (https:// doi.org/10.7150/thno.43834)

Wehrenberg U, Ivell R \& Walther N 1992 The COUP transcription factor (COUP-TF) is directly involved in the regulation of oxytocin gene expression in luteinizing bovine granulosa cells. Biochemical and Biophysical Research Communications 189 496-503. (https://doi. org/10.1016/0006-291x(92)91585-e)

Wei J \& Zhao Y 2020 MiR-185-5p protects against angiogenesis in polycystic ovary syndrome by targeting VEGFA. Frontiers of Pharmacology 151030.

Welch RD \& Flaveny CA 2017 REV-ERB and ROR: therapeutic targets for treating myopathies. Physical Biology 14 045002. (https://doi. org/10.1088/1478-3975/14/4/045002)

Wu L \& Chen L 2018 Characteristics of Nur77 and its ligands as potential anticancer compounds (Review). Molecular Medicine Reports 18 47934801. (https://doi.org/10.3892/mmr.2018.9515)

Wu Y, Ghosh S, Nishi Y, Yanase T, Nawata H \& Hu Y 2005 The orphan nuclear receptors NURR1 and NGFI-B modulate aromatase gene expression in ovarian granulosa cells: a possible mechanism for repression of aromatase expression upon luteinizing hormone surge. Endocrinology 146 237-246. (https://doi.org/10.1210/en.2004-0889)

Wu S, Sun H, Zhang Q, Jiang Y, Fang T, Cui I, Yan G \& Hu Y 2015 MicroRNA-132 promotes estradiol synthesis in ovarian granulosa 
cells via translational repression of Nurr1. Reproductive Biology and Endocrinology 13 94. (https://doi.org/10.1186/s12958-015-0095-z)

Wu Y, Zhang Q \& Zhang R 2017 Kaempferol targets estrogen-related receptor alpha and suppresses the angiogenesis of human retinal endothelial cells under high glucose conditions. Experimental and Therapeutic Medicine 14 5576-5582. (https://doi.org/10.3892/etm.2017.5261)

Wulff C, Wiegand SJ, Saunders PT, Scobie GA \& Fraser HM 2001 Angiogenesis during follicular development in the primate and its inhibition by treatment with truncated Flt-1-Fc (vascular endothelial growth factor Trap(A40)). Endocrinology 142 3244-3254. (https://doi. org/10.1210/endo.142.7.8258)

Wulff C, Wilson H, Wiegand SJ, Rudge JS \& Fraser HM 2002 Prevention of thecal angiogenesis, antral follicular growth, and ovulation in the primate by treatment with vascular endothelial growth factor TRAP R1R2. Endocrinology $143 \quad$ 2797-2807. (https://doi.org/10.1210/ endo.143.7.8886)

Xiao L, Wang J, Li J, Chen X, Xu P, Sun S, He D, Cong Y \& Zhai Y 2015 ROR $\alpha$ inhibits adipocyte-conditioned medium-induced colorectal cancer cell proliferation and migration and chick embryo chorioallantoic membrane angiopoiesis. American Journal of Physiology, Cell Physiology 308 C385C396. (https://doi.org/10.1152/ajpcell.00091.2014)

Xing W, Danilovich N \& Sairam MR 2002 Orphan receptor chicken ovalbumin upstream promoter transcription factors inhibit steroid factor-1, upstream stimulatory factor, and activator protein-1 activation of ovine follicle-stimulating hormone receptor expression via composite cis-elements. Biology of Reproduction 66 1656-1666. (https://doi. org/10.1095/biolreprod66.6.1656)

Xu M, Qin J, Tsai SY \& Tsai MJ 2015 The role of the orphan nuclear receptor COUP-TFII in tumorigenesis. Acta Pharmacologica Sinica 36 32-36. (https://doi.org/10.1038/aps.2014.86)

Xue K, Liu JY, Murphy BD \& Tsang BK 2012 Orphan nuclear receptor NR4A1 is a negative regulator of DHT-induced rat preantral follicular growth. Molecular Endocrinology 26 2004-2015. (https://doi. org/10.1210/me.2012-1200)

Yang X, Feng S \& Tang K 2017 COUP-TF genes, human diseases, and the development of the central nervous system in murine models. Current Topics in Developmental Biology 125 275-301. (https://doi.org/10.1016/ bs.ctdb.2016.12.002)

Ye T, Peng J, Liu X, Hou S, Niu G, Li Y, Zeng H \& Zhao D 2019 Orphan nuclear receptor TR3/Nur77 differentially regulates the expression of integrins in angiogenesis. Microvascular Research 122 22-33. (https:// doi.org/10.1016/j.mvr.2018.10.011)

Yu X \& Ye F 2020 Role of angiopoietins in development of cancer and neoplasia associated with viral infection. Cells 9 457. (https://doi. org/10.3390/cells9020457)

Yu RN, Ito M, Saunders TL, Camper SA \& Jameson JL 1998 Role of Ahch in gonadal development and gametogenesis. Nature Genetics 20 353-357. (https://doi.org/10.1038/3822)

Zamora-Gutiérrez D, Guzmán A, Hernández-Coronado CG, CastilloJuárez H, Fierro F, Gutiérrez CG, Bojalil R \& Rosales-Torres AM 2019 Co-ordinated expression of the VEGF system components in granulosa cells to develop a proangiogenic autocrine milieu during ovarian follicle development. Molecular Reproduction and Development 86 156-165. (https://doi.org/10.1002/mrd.23089)

Zeebaree BK, Kwong WY, Mann GE, Gutierrez CG \& Sinclair KD 2018 Physiological responses of cultured bovine granulosa cells to elevated temperatures under low and high oxygen in the presence of different concentrations of melatonin. Theriogenology 105 107-114. (https://doi. org/10.1016/j.theriogenology.2017.09.014)

Zeleznik AJ, Schuler HM \& Reichert Jr LE 1981 Gonadotropin-binding sites in the rhesus monkey ovary: role of the vasculature in the selective distribution of human chorionic gonadotropin to the preovulatory follicle. Endocrinology 109 356-362. (https://doi.org/10.1210/endo-109-2-356)

Zeng H, Qin L, Zhao D, Tan X, Manseau EJ, Van Hoang M, Senger DR, Brown LF, Nagy JA \& Dvorak HF 2006 Orphan nuclear receptor TR3/Nur77 regulates VEGF-A-induced angiogenesis through its transcriptional activity. Journal of Experimental Medicine 203 719-729. (https://doi.org/10.1084/jem.20051523)
Zetterström RH, Solomin L, Jansson L, Hoffer BJ, Olson L \& Perlmann T 1997 Dopamine neuron agenesis in Nurr1-deficient mice. Science 276 248-250. (https://doi.org/10.1126/science.276.5310.248)

Zhang Y \& Dufau ML 2001 EAR2 and EAR3/COUP-TFI regulate transcription of the rat $\mathrm{LH}$ receptor. Molecular Endocrinology 15 1891-1905. (https://doi.org/10.1210/mend.15.11.0720)

Zhang Y \& Dufau ML 2003 Dual mechanisms of regulation of transcription of luteinizing hormone receptor gene by nuclear orphan receptors and histone deacetylase complexes. Journal of Steroid Biochemistry and Molecular Biology 85 401-414. (https://doi.org/10.1016/s09600760(03)00230-9)

Zhang X, Gaspard JP \& Chung DC 2001 Regulation of vascular endothelial growth factor by the Wnt and K-ras pathways in colonic neoplasia. Cancer Research 61 6050-6054.

Zhang Y, Hagedorn CH \& Wang L 2011a Role of nuclear receptor SHP in metabolism and cancer. Biochimica et Biophysica Acta 1812 893-908. (https://doi.org/10.1016/j.bbadis.2010.10.006)

Zhang K, Lu J, Mori T, Smith-Powell L, Synold TW, Chen S \& Wen W 2011 b Baicalin increases VEGF expression and angiogenesis by activating the ERR\{alpha\}/PGC-1\{alpha\} pathway. Cardiovascular Research 89 426-435. (https://doi.org/10.1093/cvr/cvq296)

Zhang LD, Chen L, Zhang M, Qi HJ, Chen L, Chen HF, Zhong MK, Shi XJ \& Li QY 2015 Downregulation of ERR $\alpha$ inhibits angiogenesis in human umbilical vein endothelial cells through regulating VEGF production and PI3K/Akt/STAT3 signaling pathway. European Journal of Pharmacology 769 167-176. (https://doi.org/10.1016/j.ejphar.2015.11.014)

Zhao D, Desai S \& Zeng H 2011 VEGF stimulates PKD-mediated CREBdependent orphan nuclear receptor Nurr1 expression: role in VEGFinduced angiogenesis. International Journal of Cancer 128 2602-2612. (https://doi.org/10.1002/ijc.25600)

Zhao H, Li Z, Cooney AJ \& Lan ZJ 2007 Orphan nuclear receptor function in the ovary. Frontiers in Biosciences-Landmark 12 3398-3405. (https:// doi.org/10.2741/2321)

Zhao S, Zhou L, Niu G, Li Y, Zhao D \& Zeng H 2014 Differential regulation of orphan nuclear receptor TR3 transcript variants by novel vascular growth factor signaling pathways. FASEB Journal 28 4524-4533. (https:// doi.org/10.1096/fj.13-248401)

Zhao H, Liu S, Ma C, Ma S, Chen G, Yuan L, Chen L \& Zhao H 2019 Estrogen-related receptor $\gamma$ induces angiogenesis and extracellular matrix degradation of temporomandibular joint osteoarthritis in rats. Frontiers in Pharmacology 10 1290. (https://doi.org/10.3389/fphar.2019.01290)

Zhou C, Tsai SY \& Tsai M 2000 From apoptosis to angiogenesis: new insights into the roles of nuclear orphan receptors, chicken ovalbumin upstream promoter-transcription factors, during development. Biochimica et Biophysica Acta 1470 M63-M68. (https://doi.org/10.1016/s0304419x(00)00005-6)

Zhou L, Cui P, Zhao S, Ye T, Li Y, Peng J, Niu G, Zhao D \& Zeng H 2016 Differential function and regulation of orphan nuclear receptor TR3 isoforms in endothelial cells. Tumour Biology 37 3307-3320. (https:// doi.org/10.1007/s13277-015-4157-9)

Zhu N, Wang H, Wei J, Wang B, Shan W, Lai X, Zhao Y, Yu J \& Huang H 2016 NR2F2 regulates bone marrow-derived mesenchymal stem cellpromoted proliferation of Reh cells. Molecular Medicine Reports 14 1351-1356. (https://doi.org/10.3892/mmr.2016.5389)

Zou C, Yu S, Xu Z, Wu D, Ng CF, Yao X, Yew DT, Vanacker JM \& Chan FL 2014 ERR $\alpha$ augments HIF-1 signalling by directly interacting with HIF$1 \alpha$ in normoxic and hypoxic prostate cancer cells. Journal of Pathology 233 61-73. (https://doi.org/10.1002/path.4329)

Received 17 March 2021

First decision 4 May 2021

Revised manuscript received 6 July 2021

Accepted 16 July 2021 